Avoimesti luettavissa osoitteessa http://journal.fi/ainedidaktiikka

\title{
Studiosta steissille - Multimodaaliset kuuntelutehtävät ylioppilastutkinnon pitkien oppimäärien kielikokeissa 2018
}

\author{
Raili Hildén, Anna von Zansen ja Emma Laihanen
}

Kasvatustieteellinen tiedekunta, Helsingin yliopisto

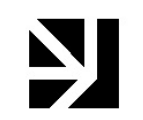

Tässä tutkimuksessa tarkasteltiin ylioppilastutkinnon kielikokeissa esiintyvien kuullunymmärtämistehtävien reiluutta ja tarkoituksenmukaisuutta. Keskityimme multimodaalisiin tehtävätyyppeihin, jotka tulivat mahdolliseksi digitaalisen ylioppilastutkinnon myötä. Aineisto käsitti englannin $(n=37086)$, ruotsin $(n=1626)$ ja saksan $(n=491)$ pitkien oppimäärien kokeisiin vuonna 2018 osallistuneiden kokelaiden osiokohtaiset pistemäärät, joita analysoitiin tilastollisin menetelmin. Lisäksi kyseisten kokeiden koetehtäviä ja niiden kuvauksia analysoitiin teorialähtöisellä sisällönanalyysillä. Multimodaaliset tehtävät edellyttävät kielitaidon lisäksi monilukutaitoa eli monimuotoisten tekstien ja niiden yhdistelmien tulkintaa. Eri kohderyhmien välisiä eroja tutkittaessa havaittiin joitakin eroja englannissa poikien ja ruotsinkielisten ja ruotsissa tyttöjen eduksi. Tasa-arvoisimmiksi osoittautuivat saksan kokeet. Tulokset hyödyttävät koetehtävien laatijoiden lisäksi kielten opetuksen parissa työskenteleviä.

Kuullun ymmärtäminen, kielitaidon arviointi, digitaalinen ylioppilastutkinto, multimodaalisuus

Lähetetty: 2.11.2020

Hyväksytty: 7.4.2021

Vastuukirjoittaja: raili.hilden@helsinki.fi

DOI: $10.23988 / \mathrm{ad} .99186$ 


\section{Johdanto}

Suomessa on vähän erityisen isoja ja tärkeitä kielikokeita. Suurelle yleisölle tutuin niistä lienee ylioppilastutkinto, jossa kymmenet tuhannet kokelaat osoittavat osaamisensa kaksi kertaa vuodessa. Ylioppilastutkinnon kielikokeet ovat niin sanottuja high-stakes-kokeita, joilla on mittavia vaikutuksia suorittajiensa tulevaisuuteen. Siksi niiden on oltava korkealaatuisia, mitä tulee koetehtäviin ja niiden laadintaprosessiin, kokeen yhdenvertaiseen toimeenpanoon, arvioinnin virheettömyyteen ja kokeen oikeudenmukaisiin seurauksiin ja yhteiskunnallisiin vaikutuksiin. Ylioppilastutkinnon kokeiden kehittämisessä pyritään huomioimaan opetussuunnitelmapainotusten ohella myös ajankohtainen tieteellinen tieto, ja esimerkiksi kielikokeisiin on vaikuttanut kansainvälinen, erityisesti eurooppalainen, kielitaito- ja validiustutkimus (mm. EVK, 2003). Eniten tutkimustietoa on ylioppilastutkinnon kielikokeiden linkityksestä EVK-taitotasoihin (Kaftandjieva \& Takala, 2002; Juurakko-Paavola \& Takala, 2013, 2017; Juurakko-Paavola, 2019). Lisäksi on tutkittu sukupuolten välisiä eroja ruotsin kielen kokeissa (Juurakko-Paavola, 2016) sekä kuullun ymmärtämisen tehtäviä (Anckar, 2011). Tutkinnon kielikokeiden sisältöjä ja validiuspiirteitä on kuitenkin tutkittu varsin niukasti. Erityisen tärkeää ja ajankohtaista on tutkinnossa aiemmin hyödyntämättömien multimodaalisten tehtävätyyppien validiuden tarkastelu (Chung, 2017).

Tutkimuksen tavoitteena on koetella ylioppilastutkinnon kielikokeissa esiintyvien kuullunymmärtämistehtävien reiluutta, mielekkyyttä ja tarkoituksenmukaisuutta. Tutkimus konkretisoi opetussuunnitelman ja ylioppilastutkinnon kielikokeiden kielitaitokäsitystä etenkin kuullun ymmärtämisen osalta. Käytämme tutkittavasta taidosta rinnan termejä kuullun ymmärtäminen ja kuunteleminen. Edellinen on käytössä ylioppilaskokeissa, jälkimmäinen taas uudemmissa opetussuunnitelmateksteissä.

Artikkelimme on suunnattu koetehtävien laatijoille, lukion kielten opettajille, täydennyskoulutusten järjestäjille ja oppimateriaalien laatijoille antamaan uusia näkökulmia kuullun ymmärtämisen harjoitteluun ja arviointiin. Tutkimusaineistona ovat ylioppilastutkinnon (YTL, 2020c) englannin, saksan ja ruotsin pitkien oppimäärien kokeet vuodelta 2018 (Abitreenit, 2018a-f). Ne sisältävät neljää kielellistä osataitoa mittaavia tehtäviä, joista tässä artikkelissa keskitymme kuullun ymmärtämisen tehtäviin. Tarkastelemme etenkin multimodaalisia kuuntelutehtäviä, jotka tulivat mahdollisiksi ylioppilastutkinnon kielikokeiden muututtua digitaaliseksi asteittain vuosien 2016 ja 2019 aikana. Multimodaalisilla tehtävillä tarkoitamme videoon perustuvia monivalintaosioita ja avoimia kysymyksiä sekä kuuntelutehtäviä, joiden vastausvaihtoehdot on esitetty perinteisen tekstin sijaan äänitteenä tai kuvina. Nämä uudet ominaisuudet mahdollistavat aiempaa monipuolisemman tavan mitata vieraan kielen taitoa.

\section{Monilukutaito ja digitaalisuus uudistavat kielitaitokäsitystä}

Ylioppilaskokeet laaditaan mittaamaan lukion opetussuunnitelman (Opetushallitus, 2015) sisältöjä ja tavoitteita. Kielikokeiden laadinta 
perustuu Eurooppalaisen viitekehyksen (EVK, 2003) toiminnalliseen kielitaitokäsitykseen, jossa yhdistyvät kielellinen tieto ja sen monipuolinen käyttötaito (YTL, 2020a, s. 4). Keskeinen käsite opetussuunnitelmassa on monilukutaito - laajan tekstikäsityksen mukaan tekstit voivat olla kirjoitettuja ja äänitettyjä, ja ne voivat sisältää kuvia, videoita ja numeroita (Opetushallitus, 2015, s. 38). Opetussuunnitelman perusteissa (Opetushallitus, 2015) perinteisiä osataitoja on yhdistetty vastaamaan paremmin luonnollista kielenkäyttöä: Taito toimia vuorovaikutuksessa liittyy kaikkeen kielelliseen kanssakäymiseen, taito tulkita tekstejä viittaa kuullun, nähdyn ja luetun ymmärtämiseen, ja taito tuottaa tekstejä käsittää puhumisen ja kirjallisen ilmaisun. Opetussuunnitelman eheytyneestä kielikäsityksestä poiketen ylioppilastutkinnon kielikokeet perustuvat osataitoajatteluun. Niissä mitataan erikseen kuullun ja luetun ymmärtämistä, rakenteita ja sanastoa sekä kirjallista tuottamista (YTL, 2020a, s. 4).

Kuullun ymmärtämisen (Opetushallitus, 2003) ja tekstien tulkintataidon (Opetushallitus, 2015) keskimääräinen osaamistaso sekä ruotsin että englannin pitkässä oppimäärässä on B2.1 ja saksassa B1.1-B1.2. Tasolla B1 opiskelija ymmärtää selkeästi puhuttua kieltä tavallisissa arkielämän tilanteissa ja kykenee myös jonkinasteiseen päättelyyn sekä pääasioiden ja tärkeimpien yksityiskohtien erottamiseen kuulemastaan. B2tasolle siirryttäessä hän pystyy seuraamaan sisällöltään abstraktia puhetta ja monimutkaisempaa argumentointia monenlaisissa yhteyksissä. Hän pystyy myös ilmaisemaan pääkohdat kuulemastaan. (Opetushallitus, 2003, 2015.)

Paperikokeiden aikana kuullun ymmärtämistä mitattiin erillisellä kuuntelukokeella, jonka tehtävätyypit rajattiin monivalintatehtäviin, avoimiin kysymyksiin ja lyhennelmiin (ks. YTL, 2011). Lisäksi tehtävissä käytetyt äänitteet luettiin ja äänitettiin studiossa. Digitaalisen ylioppilastutkinnon myötä kielikokeet sisältävät nykyään videoita ja kuvia, mikä tuo koetta lähemmäs arkielämän vuorovaikutustilanteita. Kuvien ja videoiden käyttöön kuullun ymmärtämisen tehtävissä liittyy myös haasteita, eivätkä kaikki kielikokeen laatijat näe visuaalisuutta osana kuullun ymmärtämisen taitoa (von Zansen, 2019, s. 90). Maailmalla useat merkittävät kielikokeet käyttävätkin pääasiassa pelkkää audiota - tai korkeintaan pysäytyskuvia kuullun ymmärtämistä mittaavissa tehtävissä (Wagner \& Ockey, 2018, s. 134).

Suomalaisissa opetussuunnitelmissa (Opetushallitus, 2003, 2015, 2019) ei seikkaperäisesti luetella tekstilajeja tai osataitoja, joita kuullun ymmärtämisen opetuksessa ja arvioinnissa tulee harjoitella. Seuraavassa luvussa kuvataan aiemman arviointitutkimuksen tunnistamia kuuntelutaitoja.

\section{Kuullun ymmärtämisessä tarvitaan monia kompetensseja ja strate- gioita}

Eurooppalaisessa viitekehyksessä (EVK, 2003) kielellinen viestintätaito koostuu kielellisistä, sosiolingvistisistä ja pragmaattisista kompetensseista, joiden lisäksi kielitaitoon tarvitaan yleisiä valmiuksia ja strategioita. Kompetenssit sisältävät sekä tietoa että sen käyttötaitoa eri tilanteissa sovellettavien strategioiden avulla. Kuullun ymmärtäminen on monimutkainen kielellinen prosessi, joka edellyttää kielellistä ja ei-kielellistä tietoa 
ja taitoja. Kielellisiä ja yleisiä kompetensseja hyödynnetään ymmärtämistilanteessa vastaanottamisstrategioiden avulla. Ei-kielellisistä tiedoista esimerkiksi yleinen maailmantuntemus ja tieto aihepiiristä auttavat rajaamaan tulkintaa ja virittämään odotuksia vastaanotettavasta viestistä (skeemoista ja hypoteeseista ks. EVK, 2003, s. 109-110).

Kuullun ymmärtäminen edellyttääkin useiden kompetenssien ja prosessien hyödyntämistä samanaikaisesti (top-down ja bottom-upprosessoinnista ks. tarkemmin Buck, 2001, s. 1-3; Flowerdew \& Miller, 2005, s. 24-27). Se edellyttää foneettisen tiedon (äänteiden ja sanojen tunnistaminen), syntaktisen tiedon (sanojen yhdistäminen lauseeksi), semanttisen tiedon (sanojen ja lauseiden merkityksen ymmärtäminen) sekä pragmaattisen tiedon (viestin tulkinta kontekstissa) prosessoimista (EVK, 2003, s. 131-133; Flowerdew \& Miller, 2005, s. 30). Flowerdewn ja Millerin (2005, s. 30) ja Buckin (2001, s. 46-48) mukaan kuunteleminen edellyttää myös nonverbaalisen tiedon, kuten ilmeiden ja ruumiinkielen, prosessoimista. EVK:n (2003, s. 133) mukaan tarvitaan havaitsemis- ja dekoodaustaitoja, muistia, päättelyä, ennakointia, kuvittelukykyä, nopeaa silmäilyä sekä yhteyksien havaitsemista tekstin osien välillä.

Kuullun ymmärtäminen edellyttää siis lukuisia kompetensseja ja strategioita, joita ei voi mitata suoraan. Kokeiden laatijat joutuvat tekemään valintoja näiden välillä kutakin koetta varten. Koetehtävien vaativuuteen vaikuttavat lukuisat tekijät, jotka liittyvät koetilanteeseen, ohjeistukseen, tehtävissä esiintyvään syötteeseen, tehtävän edellyttämään vastaukseen sekä syötteen ja vastauksen väliseen suhteeseen (Bachman \& Palmer, 1996, s. 47-57). Kuullun ymmärtäminen nähdään perinteisesti (default listening construct, Buck, 2001, s. 113-114) kykynä a) prosessoida pidempiä puhenäytteitä reaaliaikaisesti, b) ymmärtää kielellistä tietoa, joka yksiselitteisesti ilmaistaan tekstissä ja c) tehdä päätelmiä kuullun katkelman perusteella. Kuullunymmärtämiskokeisiin pyritäänkin tavallisesti sisällyttämään osioita, jotka mittaavat niin eksplisiittisesti kuin implisiittisestikin ilmaistua tietoa. Osioita, jotka edellyttävät päättelyä kuullun perusteella, pidetään yleensä vaikeampina kuin osioita, joiden ratkaisu edellyttää tietyn yksityiskohdan poimimista äänitteestä (Wagner \& Ockey, 2018, s. 131-132).

\section{Reiluus ja oikeudenmukaisuus ylioppilastutkinnon kielikokeissa}

Nykyaikainen validiuskäsitys on korostuneen arvolähtöinen, ja johdonmukaista onkin, että arviointi toteuttaa yhdenvertaisuutta, tasa-arvoa ja oikeudenmukaisuutta, joille demokraattinen oikeusvaltio muutenkin rakentuu. Arvolähtöisyys luonnehtii vahvasti tässä tutkimuksessa sovellettavaa Kunnanin (2018) validiusteoriaa, jonka perusperiaatteet ovat reiluus (fairness) ja oikeudenmukaisuus (justice). Molemmilla on laaja arviointifilosofinen tausta, joka ei ole tämän artikkelin keskiössä. Yksinkertaisimmillaan reiluuden ydin on, että arviointi, koe tai testi kohtelee kutakin arvioitavaa yhdenvertaisesti. Oikeudenmukaisuus taas viittaa arvioinnin yhteiskunnallisesti suotuisiin seurauksiin (Kunnan, 2018, s. 80-81). Molempien periaatteiden toteutumista tarkastellaan Toulminin argumentaatiomallin (Toulmin, 2003) mukaisesti laatimalla väitteitä pätevän arvioinnin ihannetilasta ja koettelemalla niitä empiirisen näytön valossa. Kielitaidon arvioinnissa Toulminin logiikkaa ovat aiemmin soveltaneet muun muassa Kane (2006) ja Bachman ja Palmer (2010) malleissaan, 
joissa korostuu arvioinnin pätevyyteen kohdistuva näyttöperustainen argumentointi ja arvioinnin käyttö oikeudenmukaisiin tarkoituksiin.

Kunnanin (2018) mallin kaksi perusperiaatetta jakautuvat edelleen useisiin alaperiaatteisiin, joista esitellään seuraavaksi tämän tutkimuksen kannalta relevantit. Reiluuden perusperiaatteen mukaan ylioppilastutkinnon kielikokeet tarjoavat kaikille kokelaille yhdenvertaiset mahdollisuudet osoittaa kielitaitonsa. Reiluuden ensimmäinen alaperiaate koskee kaikkien kokelaiden mahdollisuutta hankkia arvioitava kielitaito. Koska kaikki kokelaat ovat suorittaneet tutkittujen kieliaineiden lukiokurssit, voidaan heillä katsoa olleen yhdenvertaiset mahdollisuudet koetehtävien tarkoittamien taitojen hankkimiseen (Kunnan, 2018, s. 95-96). Koska ylioppilastutkinto mittaa lukion opetussuunnitelman tavoitteiden toteutumista, tutkinnon koetehtävien voidaan olettaa pyrkivän vastaamaan opetussuunnitelman perusteissa kuvattuja tietoja ja taitoja.

Toinen alaperiaate tarkoituksenmukaisuus (meaningfulness) liittyy opetussuunnitelman tavoitteisiin, mitattavaan kielitaitokäsitteeseen sekä koeaineiston kieleen, sisältöön ja aiheisiin. Koetuloksen pitää pystyä ennustamaan suoriutumista tulevissa kielenkäyttötilanteissa tai muissa kokeissa. Sen tulee olla johdonmukainen myös suhteessa osioiden ja tehtävien mittaamiin kielitaidon osa-alueisiin (Kunnan, 2018, s. 96-97). Kolmannen reiluusperiaatteen mukaan koetulos ei sisällä systemaattista vaihtelua, joka liittyy tehtävien kielimuotoon, sisältöihin tai aiheisiin eivätkä osaamiseltaan tasavertaiset suorittajat saa eri pistemääriä johtuen yksilöllisistä piirteistä kuten sukupuolesta tai etnisestä taustasta (Kunnan, 2918, s. 97-98). Neljäs reiluusperiaate edellyttää, että kielikokeen saavutettavuus, toimeenpano ja pisterajojen asettamisprosessit ovat yhdenvertaisia kaikille kokelaille (Kunnan, 2018, s. 97-98). Nämä seikat on pyritty turvaamaan tutkinnon toimeenpano-ohjeissa (YTL, 2020c).

Suomessa on vakiintunut tapa tarkastella oppimistuloksia tiettyjen tasa-arvoulottuvuuksien kannalta, joista yleisimpiä ovat sukupuoli, kotikieli, koulun opetuskieli, koulun sijaintialue ja vanhempien sosioekonominen tausta. Nämä muuttujat ovat käytössä muun muassa perusopetuksen oppimistulosarvioinneissa (Kansallinen koulutuksen arviointikeskus, 2020). Perinteisten tasa-arvonäkökulmien lisäksi koulutuksen on oltava yhdenvertaista. Tässä yhteydessä ei paneuduta näiden käsitteiden monisyisiin määritelmiin ja eroihin, vaan keskitytään tässä vaiheessa sukupuolen, koulun opetuskielen ja koulun sijaintialueen vertailuun. Tämä tutkimus kohdentuu reiluuden toiseen ja kolmanteen alaperiaatteeseen eli tarkoituksenmukaisuuteen ja koetulosten yhdenvertaisuuteen.

\section{Tutkimuskysymykset}

Seuraavat kaksi tutkimuskysymystä kohdistuvat kokeen reiluuteen tutkittujen multimodaalisten tehtävien ja osioiden kannalta. Tutkimuskysymykset ovat:

1. Mitä opetussuunnitelman perusteiden edellyttämiä kompetensseja ja strategioita tutkitut multimodaaliset tehtävät ja osiot mittaavat? 
2. Miten tasavertaisesti eri kokelasryhmät menestyvät tutkituissa osioissa?

Ensimmäinen tutkimuskysymys pureutuu kokeen mielekkyyteen ja tarkoituksenmukaisuuteen, johon kuuluu myös se, missä määrin tehtävät vastaavat kokelaan lukio-opiskelun aikaisia opetussuunnitelman perusteita sekä käsitesisällön että suoritusprosessin osalta (Kunnan, 2018, s. 96-97). Kuullun ymmärtämisen käsitesisältöä tarkastellaan osioiden ratkaisun vaatimien kompetenssien ja strategioiden avulla.

Toinen tutkimuskysymys kohdentuu siihen, miten eri sukupuolia, alueita ja koulun opetuskieliä edustavat kokelaat suoriutuvat tehtävistä ja onko kokelasryhmien välillä systemaattisia eroja.

\section{Menetelmät}

Tässä artikkelissa ylioppilastutkinnon kielikokeilla tarkoitetaan vieraan ja toisen kotimaisen kielen kokeita. Pitkällä oppimäärällä tarkoitetaan perusopetuksen vuosiluokilla 1.-6. alkanutta oppimäärää (LOPS, 2003, 2015). Kielikokeet koostuvat osakokeista, jotka mittaavat tiettyä taitoa, kuten kuullun ymmärtämistä. Osakoe puolestaan sisältää tehtäviä, jotka koostuvat yhdestä tai useammasta osiosta. Yleisellä tasolla puhutaan koetehtävistä.

Tutkimuksen aineisto koostuu vuoden 2018 kevään ja syksyn ylioppilastutkinnon ruotsin, englannin ja saksan pitkien oppimäärien tehtävistä. Kokeiden lisäksi aineistona on kokeisiin osallistuneiden kokelaiden osiokohtaiset pisteet. Näiden ohella on käytetty myös koetehtäviä laatineiden jaosten tekemiä kuvauslomakkeita. Kuvauslomakkeissa ilmoitetaan osioiden enimmäispistemäärät, suunniteltu taitotaso (kunkin osion ja tekstin), tehtävätyyppi (esim. monivalintakysymys vai avoin tehtävä), tekstityyppi (esim. kertova, kuvaileva), aihe (esim. musiikki, luonto), autenttisuusaste (esim. onko tekstiä muokattu koetta varten), sisällön vaativuus (konkreettisuusaste) sekä sanaston ja rakenteiden vaativuus. Lisäksi kuvataan äänitteen puhenopeus, kuuntelukertojen määrä ja kielivariantti. Kuvauslomakkeissa määritellään myös, mihin lukion kursseihin tehtävä liittyy ja ilmoitetaan oikeat vastaukset.

Ruotsin ylioppilaskokeeseen keväällä 2018 osallistui 1071 kokelasta ja syksyllä 555 kokelasta. Englannin ylioppilaskokeeseen osallistui keväällä 20189 kokelasta ja syksyllä 16897 kokelasta. Saksan kokeen suoritti keväällä 397 kokelasta ja syksyllä 94 kokelasta. Enemmistö kokelaista oli kussakin kielessä tyttöjä, ja suurin osa kouluista opetuskieleltään suomenkielisiä. Taulukossa 1 on esitetty kokelasmäärät taustamuuttujittain eri kokeissa. 
Taulukko 1. Kokelaiden sukupuoli, koulun kieli ja yhteismäärä ruotsin, englannin ja saksan pitkän oppimäärän vuoden 2018 ylioppilaskokeissa

\begin{tabular}{|c|c|c|c|c|c|c|c|c|c|c|c|c|c|}
\hline \multirow{2}{*}{\multicolumn{2}{|c|}{ Koe }} & \multicolumn{2}{|c|}{ RU/K } & \multicolumn{2}{|c|}{ RU/S } & \multicolumn{2}{|c|}{ EN/K } & \multicolumn{2}{|c|}{ EN/S } & \multicolumn{2}{|c|}{ SA/K } & \multicolumn{2}{|c|}{ SA/S } \\
\hline & & $\mathrm{N}$ & $\%$ & $\mathrm{~N}$ & $\%$ & $\mathrm{~N}$ & $\%$ & $\mathrm{~N}$ & $\%$ & $\mathrm{~N}$ & $\%$ & $\mathrm{~N}$ & $\%$ \\
\hline \multirow{2}{*}{ Sukupuoli } & Poika & 301 & 28,1 & 157 & 28,3 & 8061 & 39,9 & 7560 & 44,7 & 138 & 34,8 & 24 & 25,5 \\
\hline & Tyttö & 765 & 71,4 & 393 & 70,8 & 12109 & 60,0 & 9316 & 55,1 & 254 & 64,0 & 70 & 74,5 \\
\hline \multirow[t]{2}{*}{ Opetuskieli } & Suomi & 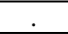 & . & . & . & 18911 & 93,7 & 15312 & 90,6 & 376 & 94,7 & 92 & 97,9 \\
\hline & Ruotsi & & & & . & 1260 & 6,2 & 1565 & 9,3 & 16 & 4,0 & 2 & 2,1 \\
\hline \multicolumn{2}{|l|}{ Yhteensä } & 1071 & 100 & 555 & 100 & 20189 & 100 & 16897 & 100 & 397 & 100 & 94 & 100 \\
\hline
\end{tabular}

Alueiden välisten erojen tarkastelussa kokelaat on jaettu aluehallintovirastojen toimialueiden mukaisesti kahdeksaan eri alueeseen: Etelä-Suomi, Itä-Suomi, Lappi, Lounais-Suomi, Länsi- ja Sisä-Suomi, Pohjois-Suomi sekä Ahvenanmaa.

Tutkimuksen aineisto saatiin Ylioppilastutkintolautakunnalta vuoden 2019 aikana. Aineistoa käsiteltiin ja sen analyysit tehtiin IBM SPSS Statistics 25 -tilasto-ohjelmalla. Tilastollisista menetelmistä tässä tutkimuksessa käytettiin ratkaisuosuuksia, Pearsonin korrelaatiokerrointa, kahden riippumattoman otoksen t-testiä sekä yksisuuntaista varianssianalyysia. Ratkaisuosuuksien avulla tarkasteltiin, kuinka suuri osuus kokelaista oli ratkaissut kyseisen osion. Näin saatiin viitettä monivalintatai avokysymysten vaikeustasosta kyseisessä kokelasjoukossa. Kahden riippumattoman otoksen t-testillä verrattiin eri taustamuuttujien (sukupuoli, koulun opetuskieli) keskiarvoja. Varianssianalyysia käytettiin alueiden välisiä eroja tarkasteltaessa, kun ryhmiä oli useampi kuin kaksi. Merkitsevyystasoina kaikissa testeissä käytettiin p-arvon merkitsevyystasoja $0.05(*)$ melkein merkitsevä, $0.01(* *)$ merkitsevä ja $0.001(* * *)$ erittäin merkitsevä.

Kuuntelutehtävän vaativuuteen vaikuttavista tekijöistä tässä tutkimuksessa käsitellään tehtäväohjeiden, syötteen ja odotetun vastauksen piirteitä (Bachman \& Palmer, 1996, s. 49-50). Osioiden tekstuaaliset ja rakenteelliset ominaisuudet sekä ajalliset suoritusehdot esitellään kuvaustaulukossa, jossa ilmoitetaan kysymyksen kieli, tehtävätyppi, aihepiiri ja kielelliset piirteet.

Kokeiden kuullun ymmärtämistä mittaavat tehtävät analysoitiin teorialähtöisellä sisällönanalyysillä. Ensin todettiin tehtävien ja osioiden ratkaisemiseen tarvittavat kompetenssit ja strategiat. Sitten havainnoista muodostettiin kategorioita (esim. yksityiskohdan ymmärtäminen, johtopäätöksen tekeminen, multimodaalinen tulkinta). Sisällönanalyysin tulokset löytyvät tulosluvussa esiteltävien kuvaustaulukoiden oikeanpuolimmaisesta sarakkeesta. Analyysin lähtökohtina olivat opetussuunnitelman (Opetushallitus 2003, 2015) sisällöt, Eurooppalaisen viitekehyksen (EVK, 2003) toiminnallinen kielitaitokäsitys sekä Buckin (2001, s. 113114) ja Flowerdewn ja Millerin (2005, s. 30) mallit kuullun ymmärtämisestä. 


\section{Tulokset}

Esittelemme seuraavaksi vastauksia tutkimuskysymyksiin sekä laadullisesta (tutkimuskysymys 1) että määrällisestä näkökulmasta (tutkimuskysymys 2). Tulosluvun alaluvut etenevät tehtävätyypeittäin. Kokeisiin voi tutustua Abitreenien (2018a-f, n.d.) verkkosivujen sekä YTL:n (2020b) julkaisemien hyvän vastauksen piirteiden avulla.

\section{Kuvaan perustuvissa monivalintaosioissa vaaditut kompetenssit ja strategiat}

Kuvia käytettiin kuullun ymmärtämisen monivalintaosioissa aineiston (Abitreenit, 2018a-f) jokaisessa kokeessa saksan kevään 2018 koetta lukuun ottamatta. Jatkossa näihin viitataan termillä kuvamonivalintatehtävä tai -osio. Seuraavaksi erittelemme kompetensseja ja strategioita, joita osion ratkaiseminen edellyttää.

Englannin jalkapallotehtävän osion 5.1 ratkaisu edellytti kolmen värillisen kuvan tulkintaa ja näistä sopivan vaihtoehdon valintaa kuullun äänitteen perusteella. Englannin taidetehtävän osion 3.2 ratkaiseminen edellytti kolmen mustavalkoisen kuvan tulkintaa sekä johtopäätöksen tekemistä videokuvan perusteella. Osion ratkaiseminen edellytti jossain määrin puhujan näkökulmaan samaistumista. Kuullun kielellisen sisällön lisäksi tarvittiin jossain määrin myös videolla esiintyvien kuvien ja tekstien lukemista sekä näiden elementtien tulkintaa.

Ruotsin naprapaattiosioiden (5.1-5.3 Välj rätt bild) ratkaiseminen edellytti ensisijaisesti tärkeiden yksityiskohtien ymmärtämistä ja kuvien tulkintaa. Lisäksi tuli ymmärtää kuullut ohjeet ja hallita erityisesti ruumiinosiin ja liikkeeseen liittyvää sanastoa.

Ruotsin muovitekstin kuvamonivalintaosion (5.4) ratkaiseminen edellytti kolmen värillisen kuvan tulkintaa ja äänitteellä kuullun tärkeän yksityiskohdan ymmärtämistä. Oleellista osion ratkaisemisessa oli etenkin äänitteellä esiintyvän sanaston ymmärtäminen (ru. larv, 'toukka') tai puuttuvan sanastovaraston kompensoiminen esimerkiksi päättelemällä tuntemattomien sanojen merkitys muun tekstin avulla (esim. kalastajat käyttävät niitä syöttinä).

Saksan lipputehtävän osioiden (3.1-3.3) ratkaisemiseksi tuli ymmärtää tärkeät yksityiskohdat kuten värit, muodot ja niiden järjestys. Lisäksi kuunnellessa täytyi pystyä karsimaan seitsemästä vaihtoehdosta sopimattomia lippuja, sillä joissakin lipuissa oli samoja värejä, ja ratkaiseva ero oli tietty yksityiskohta.

Seuraavassa taulukossa (Taulukko 2) on yhteenveto monivalintaosioista, joissa käytetään kuvia vastausvaihtoehtoina. 
Ainedidaktiikka 5(1) (2021)

Taulukko 2. Kuvat vaihtoehtoina monivalintaosioissa Koe / tehtävä,
(kuvamonivalinta-
osiot)
Tehtävän aineisto,

äänitteen kesto,

kuuntelukerrat, läh-

teet
Tekstityyppi, kurssit, aihepiirit, puhenopeus,

taitotaso (jaos),

abstraktiotaso, sa-

naston ja rakentei-

den vaativuus

\begin{tabular}{|c|c|c|c|}
\hline $\begin{array}{l}\text { Englanti kevät } \\
5 \text { Hillsboroug } \\
\text { Survivor(osio 5.1) }\end{array}$ & $\begin{array}{l}\text { 4x audio (á 0:20-0:49) } \\
3 x \text { värillinen kuva, } \\
1 \text { krt Wikipedia, BBC, } \\
\text { ESPN, Independent, } \\
\text { Talksport }\end{array}$ & $\begin{array}{l}\text { Kertova } \\
1,3 \\
\text { Urheilu } \\
\text { Normaali } \\
\text { B1.2 } \\
\text { Konkreettinen } \\
\text { Pääasiassa yksinker- } \\
\text { tainen }\end{array}$ & $\begin{array}{l}\text { Pääajatusta tukevan } \\
\text { tärkeän yksityiskoh- } \\
\text { dan ymmärtäminen, } \\
\text { kuvien tulkinta }\end{array}$ \\
\hline $\begin{array}{l}\text { Englanti syksy } \\
3 \text { What is art? } \\
\text { (osio 3.2) }\end{array}$ & $\begin{array}{l}\text { video }(2: 29) \\
3 x \text { mustavalkoinen } \\
\text { kuva, rajaton } \\
\text { Youtube, } \\
\text { squarespace.com, } \\
\text { cybershop.fi, } \\
\text { telegraph.co.uk }\end{array}$ & $\begin{array}{l}\text { Pohtiva } \\
3 \\
\text { Kuvataide } \\
\text { Normaali } \\
\text { B2.1 } \\
\text { Jonkin verran abst- } \\
\text { rakti } \\
\text { Jossakin määrin vaa- } \\
\text { tiva }\end{array}$ & $\begin{array}{l}\text { Johtopäätöksen teke- } \\
\text { minen, kuvien tul- } \\
\text { kinta }\end{array}$ \\
\hline $\begin{array}{l}\text { Ruotsi, kevät } \\
5 \text { Naprapate ger råd } \\
\text { (osiot 5.1-5.3) }\end{array}$ & $\begin{array}{l}\text { audio }(1: 12) \\
9 \text { värillistä kuvaa, } 2 \mathrm{krt} \\
\text { (Youtube) }\end{array}$ & $\begin{array}{l}\text { Opastava } \\
2 \\
\text { Hyvinvointi } \\
\text { Normaali } \\
\text { B2.1 } \\
\text { Konkreettinen } \\
\text { Pääasiassa yksinker- } \\
\text { tainen }\end{array}$ & $\begin{array}{l}\text { Leksikaalinen kom- } \\
\text { petenssi } \\
\text { Tärkeän yksityiskoh- } \\
\text { dan ymmärtäminen, } \\
\text { kuvien tulkinta }\end{array}$ \\
\hline $\begin{array}{l}\text { Ruotsi, syksy } \\
5 \text { Plast } \\
\text { (osio 5.4) }\end{array}$ & $\begin{array}{l}\text { audio (2:31) } \\
4 \text { värillistä kuvaa, 2krt } \\
\text { verkkosivustot: } \\
\text { Me Naiset / } \\
\text { Shutterstock, } \\
\text { Jönköpings Posten }\end{array}$ & $\begin{array}{l}\text { Kertova, kuvaileva } \\
4,7 \\
\text { Luonto } \\
\text { Normaali } \\
\text { B2.1 } \\
\text { Jonkin verran abst- } \\
\text { raktia } \\
\text { Jossakin määrin vaa- } \\
\text { tiva }\end{array}$ & $\begin{array}{l}\text { Leksikaalinen kom- } \\
\text { petenssi } \\
\text { Tärkeän yksityiskoh- } \\
\text { dan ymmärtäminen, } \\
\text { kuvien tulkinta }\end{array}$ \\
\hline $\begin{array}{l}\text { Saksa, syksy } \\
3 \text { Landesflaggen } \\
\text { (osiot 3.1-3.3) }\end{array}$ & $\begin{array}{l}3 \mathrm{x} \text { audio (kesto á } \\
0: 20-0: 23 \text { ) } \\
7 \text { värillistä kuvaa, } 2 \mathrm{krt} \\
\text { Wikipedia }\end{array}$ & $\begin{array}{l}\text { Kuvaileva } \\
4 \\
\text { Kulttuurintuntemus } \\
\text { Normaali/hidas } \\
\text { B1.1 Konkreettinen } \\
\text { Jossakin määrin vaa- } \\
\text { tiva }\end{array}$ & $\begin{array}{l}\text { Tärkeän yksityiskoh- } \\
\text { dan ymmärtäminen, } \\
\text { kuvien tulkinta (3) }\end{array}$ \\
\hline
\end{tabular}

Tutkittujen osioiden ratkaisussa tarvittavat kompetenssit ja strategiat

(TK1)

Pääajatusta tukevan tärkeän yksityiskohdan ymmärtäminen, kuvien tulkinta minen, kuvien tulkinta

Toiseen tutkimuskysymykseen liittyen tarkasteltiin kuvamonivalintaosioiden ratkaisuosuuksia, korrelaatioita ja merkitseviä eroja eri kokelasryhmien välillä. Kuten seuraavasta taulukosta (Taulukko 3) ilmenee, kuvamonivalintaosioiden ratkaisuosuudet ovat erittäin korkeita, eli osiot olivat kokelaille helppoja. Korrelaatiot (Pearson) koko kuullunymmärtämistaitoon ovat suhteellisen matalia eli tehtävät mittaavat jotain muuta kuin suurin osa muista kuuntelutehtävistä. 


\section{Ainedidaktiikka 5(1) (2021)}

Taulukko 3. Kuvamonivalintaosioiden ratkaisuosuudet ja korrelaatiot

\begin{tabular}{|c|c|c|c|c|c|c|c|c|c|c|}
\hline \multirow{2}{*}{\multicolumn{2}{|c|}{$\begin{array}{l}\text { Koe } \\
\text { Osio }\end{array}$}} & \multicolumn{3}{|c|}{$\mathbf{R U} / \mathbf{K}$} & \multirow{2}{*}{\begin{tabular}{c|}
$\mathbf{R U} / \mathbf{S}$ \\
5.4 \\
\end{tabular}} & \multirow{2}{*}{\begin{tabular}{c|}
$\mathbf{E N} / \mathbf{K}$ \\
5.1 \\
\end{tabular}} & \multirow{2}{*}{\begin{tabular}{c|}
$\mathbf{E N} / \mathbf{S}$ \\
3.2 \\
\end{tabular}} & \multicolumn{3}{|c|}{$\mathbf{S A} / \mathbf{S}$} \\
\hline & & 5.1 & 5.2 & 5.3 & & & & 3.1 & 3.2 & 3.3 \\
\hline \multicolumn{2}{|l|}{ Ratkaisuosuus (\%) } & 97,5 & 86,1 & 90,3 & 78,9 & 86,1 & 85,2 & 96,8 & 96,8 & 100,0 \\
\hline \multicolumn{2}{|c|}{ Korrelaatio kuullun ymmärtämiseen } & .301 & .378 & .382 & .527 & .350 & .257 & .052 & .327 & . \\
\hline \multicolumn{2}{|l|}{ Korrelaatio koko kokeeseen } & .343 & .373 & .373 & .437 & .319 & .228 & .115 & .209 & . \\
\hline \multirow{3}{*}{$\begin{array}{l}\text { Merkitsevä ero sukupuolten } \\
\text { välillä }\end{array}$} & $\mathrm{t}$ & .265 & .726 & 1.095 & 4.148 & 16.450 & -1.402 & -1.668 & -.312 & . \\
\hline & df & 1062 & 1063 & 1063 & 546 & 20077 & 16828 & 92 & 92 & . \\
\hline & $\mathrm{p}$ & .791 & .468 & .274 & $.000^{* * *}$ & $.000^{* * *}$ & .161 & .099 & .756 & . \\
\hline \multirow{3}{*}{$\begin{array}{l}\text { Merkitsevä ero opetuskielten } \\
\text { välillä }\end{array}$} & $\mathrm{t}$ & . & . & . & . & -4.265 & -1.691 & -.257 & -.257 & . \\
\hline & df & . & . & . & . & 20078 & 16829 & 92 & 92 & . \\
\hline & $\mathrm{p}$ & . & . & . & . & $.000 * * *$ & .091 & .798 & .798 & . \\
\hline \multirow[t]{3}{*}{ Merkitsevä ero alueiden välillä } & $\mathrm{F}$ & 3.488 & 6.949 & 7.538 & 5.802 & 4.336 & 4.890 & .239 & 2.397 & . \\
\hline & $\mathrm{df}$ & 5 & 5 & 5 & 5 & 6 & 6 & 4 & 4 & . \\
\hline & $\mathrm{p}$ & $.004 * *$ & $.000 * * *$ & $.000 * * *$ & $.000^{* * *}$ & $.000 * * *$ & $.000 * * *$ & .916 & .056 & . \\
\hline
\end{tabular}

Studentin t-testi osoitti, että tyttöjen ja poikien keskiarvot erosivat tutkituissa kuvamonivalintaosioissa toisistaan merkitsevästi ainoastaan ruotsin syksyn (Abitreenit, 2018d) osiossa 5.4 ja englannin kevään (Abitreenit, 2018a) osiossa 5.1. Pojat pärjäsivät näissä osioissa paremmin kuin tytöt. Englannin ja saksan kokeissa (Abitreenit, 2018abef) ero oli tutkituissa kuvamonivalintaosioissa merkitsevä suomen- ja ruotsinkielisten kokelaiden välillä ainoastaan kevään 2018 englannin (Abitreenit, 2018a) osiossa 5.1 , jossa ruotsinkieliset kokelaat menestyivät suomenkielisiä paremmin. Tutkituissa osioissa merkitseviä eroja alueiden välillä ilmeni ainoastaan ruotsin ja englannin kokeissa: Lappi ja Etelä-Suomi pärjäsivät parhaiten kevään ruotsin kokeessa, Itä-Suomi puolestaan huonoimmin. Englannin kokeessa tutkittujen osioiden perusteella Ahvenanmaa pärjäsi parhaiten ja Itä-Suomi ja Lappi heikoimmin.

\section{Videoon perustuvissa monivalintaosioissa vaaditut kompetenssit ja strategiat}

Aineiston kokeissa (Abitreenit, 2018a-f) esiintyi videotehtäviä, joissa tehtävätyyppinä oli monivalintaa tai avoimia kysymyksiä. Joissakin tehtävissä yhdisteltiin molempia osiotyyppejä, mikä on paperikokeeseen nähden uudenlainen käytäntö. Kielten ja kokeiden välisen vertailun mahdollistamiseksi esittelemme ensin videoon perustuvat monivalintaosiot ja seuraavassa luvussa avoimet kysymykset.

Monivalintatehtäviä, joissa aineistona on video, hyödynnettiin erityisesti pitkän englannin ja saksan ylioppilaskokeissa. Toisin kuin kuvamonivalinnoissa, videokatkelmaan perustuvissa tehtävissä vastausvaihtoehdot annettiin tekstinä, mutta tehtävän äänite sisälsi liikkuvaa kuvaa.

Englannin kevään kokeessa taidetehtävän osio 3.1 edellytti ensisijaisesti pääajatusta tukevan yksityiskohdan ymmärtämistä. Osiossa 3.2 videon perusteella tuli tehdä johtopäätös. Osioiden 3.3 ja 3.4 ratkaiseminen puolestaan edellytti pääajatusta tukevan esimerkin ymmärtämistä. Edellisten lisäksi kokelaan oli kuhunkin osioon vastatakseen löydettävä 
oikea kohta videolta, sillä videota sai katsoa rajattomasti, ja sitä pystyi myös kelaamaan ja tauottamaan (ks. von Zansen, 2019, s. 203).

Englannin syksyn kokeessa taidetehtävässä osion 3.1 ratkaiseminen edellytti videon pääajatuksen tulkintaa, osion 3.3 ratkaiseminen taas pääajatusta tukevan esimerkin ymmärtämistä. Äänitteellä esitetyn johtopäätöksen tulkintaa vaati osion 3.4 oikea ratkaisu.

Englannin vinyylilevytehtävän osioissa 5.1 ja 5.4 tuli ymmärtää yksityiskohta, ja osiossa 5.2 myös pääajatus, jota kysytty yksityiskohta tuki. Osio 5.3 vaati näiden ohella myös johtopäätöksen tekemistä kuullun perusteella. Auditiivisen syötteen lisäksi tehtävän ratkaisu edellytti myös kirjoitettujen tekstien ymmärtämistä, sillä videolla nähtävät tekstit tukivat kokonaiskuvan muodostumista.

Ruotsin tehtävä lasten asemasta Suomessa itsenäisyyden ajalla sisälsi kolme monivalintaosiota. Osion 7.1 ratkaisu edellytti ensisijaisesti pääajatusta tukevan yksityiskohdan ymmärtämistä, osion 7.2 yksityiskohdan ymmärtämistä ja osion 7.3 ratkaiseminen vaati jo päättelyä kuullun perusteella. Kokelaan täytyi löytää oikea kohta äänitteeltä yleistietonsa ja äänitteellä näkyvän vuosiluvun (1937) perusteella sekä etsiä kohta, jossa ylipäänsä puhutaan avustuksesta. Lisäksi tehtävän ratkaiseminen edellytti multimodaalista tulkintaa, sillä videolla esiintyi esimerkiksi infograafeja. Videolla vaihtuvat kuvat luultavasti tukevat selostusta, mutta taustamusiikki saattoi paikoitellen häiritä (von Zansen, 2019, s. 202, 247).

Saksan poikakuorotehtävän osioiden ratkaiseminen edellytti ensisijaisesti äänitteellä esiintyvien yksityiskohtien ymmärtämistä. Videolla kuultavien yksityiskohtien ymmärtäminen oli keskiössä myös saksan perunatehtävän osioiden $11.1,11.2$ ja 11.4 ratkaisussa. Oleellista tehtävästä suoriutumisessa oli myös multimodaalinen tulkinta, sillä videolla esiintyvien kuvien (maalauksia, karttoja, grafiikkaa) lisäksi videolla esiintyi myös animoituja avattaria. Sekä taustamusiikki että kuvakulma vaihtuivat videolla usein, joten kokonaiskuvan saaminen edellytti useampaa katselukertaa.

Saksan ravitsemustehtävän osioiden (6.1-6.3) ratkaiseminen edellytti pääajatuksen ymmärtämistä. Osiossa 6.1 kysymyksen ymmärtämistä oli helpotettu antamalla koulun opetuskielellä keskeinen sana (Suppenschüsseln $=$ keittolautanen), jota lukiolaiset eivät välttämättä tunne. Videolla esiintyvä asiantuntija puhui hyvin nopeasti, mikä on haastavaa saksaa vieraana kielenä opiskelevalle (Buck, 2001, s. 38). Videota oli ilmiselvästi leikattu, sillä katkelmat alkoivat yllättäen. Videota rytmittivät kuitenkin otsikkomaiset tekstit "Experiment 1", jotka helpottivat seuraamista. Puhujan kasvojen lisäksi näytettiin hänen käsiään, joilla hän elehti jatkuvasti - mikä vaikuttanee kuullun ymmärtämiseen (Buck, 2001, s. 47-48). Puheen lisäksi alareunaan nousi ajoittain hetkeksi lainauksia, joissa kiteytettiin puhujan johtoajatuksia, jotka olivat kenties peräisin hänen kirjoittamastaan kirjasta. Tekstien ymmärtäminen osana kuullun ymmärtämistehtävää edellytti multimodaalista tulkintaa.

Saksan keksintötehtävän osion 7.1 ratkaiseminen edellytti pääajatuksen ymmärtämistä. Osioista 7.2 ja 7.3 suoriutui ymmärtämällä tarvittavat yksityiskohdat. Kaiken kaikkiaan tehtävä perustui multimodaa- 


\section{Ainedidaktiikka 5(1) (2021)}

liseen tulkintaan. Kertojan esitellessä keksintöjä videolla nimittäin näytettiin keksintöä ja ongelmaa, johon se liittyi. Kuvallinen informaatio tuki kontekstin ja sisällön ymmärtämistä, mikä olikin tarpeen, sillä äänitteellä esiintyvä sanasto oli paikoitellen vaativaa.

Seuraavassa taulukossa (Taulukko 4) on yhteenveto videoon perustuvista monivalintaosioista.

\section{Taulukko 4. Videoon perustuvat monivalintaosiot}

\begin{tabular}{|c|c|c|c|}
\hline $\begin{array}{l}\text { Koe / tehtävä, } \\
\text { (videoon perus- } \\
\text { tuvat moniva- } \\
\text { lintaosiot) }\end{array}$ & $\begin{array}{l}\text { Tehtävän ai- } \\
\text { neisto, äänit- } \\
\text { teen kesto, } \\
\text { kuunteluker- } \\
\text { rat, lähteet }\end{array}$ & $\begin{array}{l}\text { Tekstityyppi, kurssit, } \\
\text { aihepiirit, puhenopeus, } \\
\text { taitotaso (jaos), abst- } \\
\text { raktiotaso, sanaston ja } \\
\text { rakenteiden vaativuus }\end{array}$ & $\begin{array}{l}\text { Tutkittujen osioiden rat- } \\
\text { kaisussa tarvittavat kom- } \\
\text { petenssit ja strategiat } \\
\text { (TK1) }\end{array}$ \\
\hline $\begin{array}{l}\text { Englanti, kevät } \\
3 \text { Art and } \\
\text { Intellectualism } \\
\text { (osiot 3.1-3.4) }\end{array}$ & $\begin{array}{l}\text { Video 1:20 } \\
\text { Rajaton } \\
\text { Youtube }\end{array}$ & $\begin{array}{l}\text { Kertova, kuvaileva } \\
3 \\
\text { Kuvataide } \\
\text { Normaali } \\
\text { B2.1 } \\
\text { Jonkin verran abstrakti } \\
\text { Jossakin määrin vaativa }\end{array}$ & $\begin{array}{l}\text { Yksityiskohdan ymmärtä- } \\
\text { minen; } \\
\text { Johtopäätöksen tekeminen; } \\
\text { Pääajatusta tukevan esimer- } \\
\text { kin ymmärtäminen (2) }\end{array}$ \\
\hline $\begin{array}{l}\text { Englanti, syksy } \\
3 \text { What is art? } \\
\text { (osiot } 3.1,3.3 \text {, } \\
3.4 \text { ) }\end{array}$ & $\begin{array}{l}\text { Video 2:29 } \\
\text { Rajaton } \\
\text { Youtube }\end{array}$ & $\begin{array}{l}\text { Pohtiva } \\
3 \\
\text { Kuvataide } \\
\text { Normaali } \\
\text { B2.1 } \\
\text { Jonkin verran abstrakti } \\
\text { Jossakin määrin vaativa }\end{array}$ & $\begin{array}{l}\text { Pääajatuksen tulkinta; pää- } \\
\text { ajatusta tukevan esimerkin } \\
\text { ymmärtäminen; } \\
\text { Johtopäätöksen tulkinta }\end{array}$ \\
\hline $\begin{array}{l}\text { Englanti, syksy } \\
5 \text { Vinyl Records } \\
\text { (osiot 5.1-5.4) }\end{array}$ & $\begin{array}{l}\text { Video 2:47 } \\
\text { Rajaton } \\
\text { Youtube }\end{array}$ & $\begin{array}{l}\text { Kertova, kantaa ottava } \\
3 \\
\text { Musiikki } \\
\text { Normaali } \\
\text { B1.1 } \\
\text { Pääasiassa konkreettinen } \\
\text { Pääasiassa yksinker- } \\
\text { tainen }\end{array}$ & $\begin{array}{l}\text { Multimodaalinen tulkinta } \\
\text { (video, teksti, kuvat) } \\
\text { Yksityiskohdan ymmärtä- } \\
\text { minen (2); Pääajatusta tu- } \\
\text { kevan yksityiskohdan ym- } \\
\text { märtäminen (2); } \\
\text { johtopäätöksen tekeminen }\end{array}$ \\
\hline $\begin{array}{l}\text { Ruotsi, syksy } \\
7 \text { Barnens Fin- } \\
\text { land } \\
\text { (osiot 7.1, 7.2, } \\
7.3 \text { ) }\end{array}$ & $\begin{array}{l}\text { Video 2:37 } \\
\text { Rajaton } \\
\text { Youtube }\end{array}$ & $\begin{array}{l}\text { Kuvaileva, kertova } \\
4 \\
\text { Historia } \\
\text { Normaali } \\
\text { B2.1 } \\
\text { Pääasiassa konkreettinen } \\
\text { Jossakin määrin vaativa }\end{array}$ & $\begin{array}{l}\text { Deklaratiivinen yleistieto } \\
\text { Multimodaalinen tulkinta } \\
\text { (kuvat, infograafit) } \\
\text { Pääajatusta tukevan yksi- } \\
\text { tyiskohdan ymmärtäminen; } \\
\text { yksityiskohdan ymmärtä- } \\
\text { minen; päätelmän tekemi- } \\
\text { nen }\end{array}$ \\
\hline $\begin{array}{l}\text { Saksa, kevät } \\
\text { 10 Sängerknaben } \\
\text { (osiot 10.1, 10.3, } \\
10.4 \text { ) }\end{array}$ & $\begin{array}{l}\text { Video 3:39 } \\
\text { Rajaton } \\
\text { Youtube }\end{array}$ & $\begin{array}{l}\text { Kertova, kuvailevan } \\
3 \\
\text { Musiikki } \\
\text { Normaali } \\
\text { B1.2-B2.1 } \\
\text { Konkreettinen } \\
\text { Jossain määrin vaativa }\end{array}$ & $\begin{array}{l}\text { Yksityiskohdan } \\
\text { ymmärtäminen (3) }\end{array}$ \\
\hline $\begin{array}{l}\text { Saksa, kevät } \\
11 \text { Kartoffeln } \\
\text { (osiot 11.1, 11.2, } \\
11.4 \text { ) }\end{array}$ & $\begin{array}{l}\text { Video 2:38 } \\
\text { Rajaton } \\
\text { Youtube }\end{array}$ & $\begin{array}{l}\text { Kertova, kuvailevan } \\
4 \\
\text { Historia } \\
\text { Normaali } \\
\text { B1.2-B2.2 } \\
\text { Konkreettinen } \\
\text { Jossakin määrin vaativa }\end{array}$ & $\begin{array}{l}\text { Multimodaalinen tulkinta } \\
\text { (video, kuvat, animaatio) } \\
\text { Yksityiskohdan ymmärtä- } \\
\text { minen (3) }\end{array}$ \\
\hline $\begin{array}{l}\text { Saksa, syksy } \\
6 \text { Melanie Mühl }\end{array}$ & $\begin{array}{l}\text { Video 2:54 } \\
\text { Rajaton } \\
\text { Youtube } \\
\end{array}$ & $\begin{array}{l}\text { Kertova } \\
5,8 \\
\text { Tieteenalat }\end{array}$ & $\begin{array}{l}\text { Multimodaalinen tulkinta } \\
\text { (video, tekstit) }\end{array}$ \\
\hline
\end{tabular}


Ainedidaktiikka 5(1) (2021)

\begin{tabular}{|c|c|c|c|}
\hline $\begin{array}{l}\text { (osiot 6.1, 6.2, } \\
6.3)\end{array}$ & & $\begin{array}{l}\text { Nopea } \\
\text { B1.2-B2.2 } \\
\text { Pääasiassa konkreettinen } \\
\text { Jossakin määrin vaati- } \\
\text { vaa / Erittäin vaativa }\end{array}$ & $\begin{array}{l}\text { Pääajatuksen ymmärtämi- } \\
\text { nen (3) }\end{array}$ \\
\hline $\begin{array}{l}\text { Saksa, syksy } \\
7 \text { Erfinder } \\
\text { (osiot 7.1, 7.2, } \\
7.3 \text { ) }\end{array}$ & $\begin{array}{l}\text { Video 2:22 } \\
\text { Rajaton } \\
\text { Youtube }\end{array}$ & $\begin{array}{l}\text { Kertova } \\
4,5 \\
\text { Luova toiminta } \\
\text { Normaali } \\
\text { B1.2-B2.1 } \\
\text { Pääasiassa konkreettinen } \\
\text { Jossakin määrin vaativa } \\
\text { / Erittäin vaativa } \\
\end{array}$ & $\begin{array}{l}\text { Multimodaalinen tulkinta } \\
\text { (video, kuvat) } \\
\text { Leksikaalinen kompetenssi } \\
\text { Pääajatuksen ymmärtämi- } \\
\text { nen, yksityiskohdan } \\
\text { ymmärtäminen (2) }\end{array}$ \\
\hline
\end{tabular}

Toinen tutkimuskysymys paneutui reiluuden toteutumiseen ylioppilaskokeissa. Seuraavat taulukot (Taulukko 5, Taulukko 6) esittävät videomonivalintaosioiden ratkaisuosuudet ja korrelaatiot kielittäin. Videoon liittyvien osioiden ratkaisuosuuksissa ilmeni enemmän vaihtelua kuin kuvaosioiden ratkaisuosuuksissa. Myös osioiden korrelaatioissa koko kuullun ymmärtämisen osataitoon arvot vaihtelivat matalista keskisuuriin.

Taulukko 5. Videoon perustuvien monivalintaosioiden ratkaisuosuudet ja korrelaatiot, ruotsi ja englanti

\begin{tabular}{|c|c|c|c|c|c|c|c|c|c|c|c|c|c|c|c|}
\hline \multirow{2}{*}{\multicolumn{2}{|c|}{$\begin{array}{l}\text { Koe } \\
\text { Osio }\end{array}$}} & \multicolumn{3}{|c|}{$\mathbf{R U} / \mathbf{S}$} & \multicolumn{4}{|c|}{ EN/K } & \multicolumn{7}{|c|}{ EN/S } \\
\hline & & 7.1 & 7.2 & 7.3 & 3.1 & \begin{tabular}{|l|}
3.2 \\
\end{tabular} & 3.3 & 3.4 & 3.1 & 3.3 & 3.4 & 5.1 & 5.2 & 5.3 & 5.4 \\
\hline \multicolumn{2}{|l|}{ Ratkaisu-osuus (\%) } & 87,7 & 70,3 & 61,4 & 77,2 & 35,3 & 48,5 & 83,6 & 86,8 & 67,9 & 52,6 & 83,9 & 96,3 & 83,5 & 78,6 \\
\hline \multicolumn{2}{|c|}{\begin{tabular}{|l|} 
Korrelaatio \\
kuullun ymmärtämiseen
\end{tabular}} & .373 & .540 & .610 & .493 & .065 & .541 & .515 & .365 & .282 & .219 & .241 & .192 & .411 & .492 \\
\hline \multicolumn{2}{|l|}{$\begin{array}{l}\text { Korrelaatio koko } \\
\text { kokeeseen }\end{array}$} & .367 & .539 & .587 & .492 & .013 & .521 & .498 & .355 & .258 & .188 & .213 & .200 & .407 & .479 \\
\hline \multirow{3}{*}{$\begin{array}{l}\text { Merkitsevä ero } \\
\text { sukupuolten } \\
\text { välillä }\end{array}$} & $\mathrm{t}$ & .540 & 1.263 & 2.217 & 5.888 & -.676 & 5.228 & 3.234 & 2.541 & \begin{tabular}{|l|}
-5.197 \\
\end{tabular} & 11.531 & .577 & -.292 & 10.193 & 10.736 \\
\hline & $\mathrm{df}$ & 546 & 544 & 545 & 20122 & 20103 & 20130 & 20132 & \begin{tabular}{|l|}
16855 \\
\end{tabular} & 16853 & 16857 & 16853 & 16859 & 16855 & 16853 \\
\hline & $\mathrm{p}$ & .589 & .207 & $.027^{*}$ & $.000 * * *$ & \begin{tabular}{|l|}
.499 \\
\end{tabular} & $.000^{* * *}$ & $.001^{* *}$ & $.011^{*}$ & $.000^{* * *}$ & $.000 * * *$ & \begin{tabular}{|l|}
.564 \\
\end{tabular} & .770 & $.000^{* * *}$ & $.000^{* * *}$ \\
\hline \multirow{3}{*}{$\begin{array}{l}\text { Merkitsevä } \\
\text { ero opetuskielten } \\
\text { välillä }\end{array}$} & $\mathrm{t}$ & . & . & . & -6.963 & \begin{tabular}{|l|}
.978 \\
\end{tabular} & \begin{tabular}{|l|}
-6.153 \\
\end{tabular} & -5.278 & \begin{tabular}{|l|}
-2.888 \\
\end{tabular} & \begin{tabular}{|l|}
-3.456 \\
\end{tabular} & -2.943 & \begin{tabular}{l|}
.503 \\
\end{tabular} & -2.690 & \begin{tabular}{l|}
-2.026 \\
\end{tabular} & -5.413 \\
\hline & $\mathrm{df}$ & . & . & . & 20123 & 20104 & \begin{tabular}{|l|}
20131 \\
\end{tabular} & 20133 & 16856 & 16854 & 16858 & 16854 & 16860 & 16856 & 16854 \\
\hline & $\mathrm{p}$ & . & . & . & $.000 * * *$ & .328 & $.000 * * *$ & $.000^{* * * *}$ & \begin{tabular}{|l|}
$.004 * *$ \\
\end{tabular} & $.001^{* *}$ & $.003 * *$ & \begin{tabular}{l|l}
.615 \\
\end{tabular} & $.007^{* *}$ & $.043^{*}$ & $.000^{* * *}$ \\
\hline \multirow{3}{*}{$\begin{array}{l}\text { Merkitsevä ero } \\
\text { alueiden välillä }\end{array}$} & $\mathrm{F}$ & 2.668 & 4.556 & 3.568 & 10.252 & \begin{tabular}{|l|}
2.276 \\
\end{tabular} & \begin{tabular}{|l|}
10.118 \\
\end{tabular} & 10.437 & \begin{tabular}{|l|}
9.873 \\
\end{tabular} & 4.220 & .712 & 1.350 & 1.816 & 4.704 & 16.683 \\
\hline & $\mathrm{df}$ & 5 & 5 & 5 & 6 & 6 & 6 & 6 & 6 & 6 & 6 & 6 & 6 & 6 & 6 \\
\hline & $\mathrm{p}$ & $.021 *$ & $.000^{* * *}$ & $.003 * *$ & $.000^{* * * *}$ & .034* & $.000 * * *$ & $.000^{* * * *}$ & $.000^{* * * *}$ & $.000 * * *$ & .640 & .231 & .092 & $.000^{* * *}$ & $.000^{* * *}$ \\
\hline
\end{tabular}

Kuten taulukoista 5 ja 6 havaitaan, videoaineistoon perustuvien monivalintaosioiden keskiarvoissa ilmeni Studentin t-testissä jonkin verran tilastollisesti merkitseviä eroja tyttöjen ja poikien välillä. Ruotsissa ero oli melkein merkitsevä ainoastaan syksyn (Abitreenit, 2018d) osiossa 7.3, jossa pojat pärjäsivät tyttöjä paremmin. Pitkän englannin kevään (Abitreenit, 2018a) kokeessa erot sukupuolten välillä olivat merkitseviä osioissa 3.1, 3.3 ja 3.4. Kaikissa näissä osioissa pojat menestyivät tyttöjä paremmin. Englannin syksyn (Abitreenit, 2018b) kokeessa ero oli merkitsevä tai melkein merkitsevä osioissa 3.1, 3.3, 3.4, 5.3 ja 5.4. Tytöt pärjäsivät poikia paremmin ainoastaan osiossa 3.3. 
Myös eroja suomen- ja ruotsinkielisten kokelaiden välillä ilmeni pitkän englannin ja saksan kokeissa. Englannin kevään (Abitreenit, 2018a) kokeessa ero oli erittäin merkitsevä osioissa 3.1, 3.3 ja 3.4, joissa ruotsinkieliset kokelaat menestyivät suomenkielisiä paremmin. Syksyn (Abitreenit 2018b) kokeessa ero oli merkitsevä tai melkein merkitsevä osioissa 3.1, 3.3, 3.4, 5.2, 5.3 ja 5.4. Myös näissä osioissa ruotsinkieliset kokelaat menestyivät suomenkielisiä paremmin. Pitkän saksan vuoden 2018 ylioppilaskokeissa ero suomen- ja ruotsinkielisten välillä oli merkitsevä ainoastaan kevään (Abitreenit, 2018e) osiossa 10.4, jossa ruotsinkieliset kokelaat pärjäsivät suomenkielisiä paremmin.

Eri alueilla opiskelevien kokelaiden keskiarvot erosivat merkitsevästi tutkituissa osioissa pääasiassa ruotsin ja englannin kokeissa. Saksassa oli vain yksi melkein merkitsevä ero kevään kokeen osiossa 10.3, jossa Lappi menestyi parhaiten ja Pohjois-Suomi puolestaan huonoimmin. Ruotsin kokeissa alueellinen suoriutuminen oli parasta Etelä-Suomessa ja heikointa Pohjois-Suomessa. Englannin kokeissa Ahvenanmaa ja EteläSuomi pärjäsivät hyvin, kun taas Itä- ja Pohjois-Suomi sekä Lappi huonosti.

Taulukko 6. Videoon perustuvien monivalintaosioiden ratkaisuosuudet ja korrelaatiot, saksa

\begin{tabular}{|c|c|c|c|c|c|c|c|c|c|c|c|c|c|}
\hline \multirow{2}{*}{\multicolumn{2}{|c|}{$\begin{array}{l}\text { Koe } \\
\text { Osio }\end{array}$}} & \multicolumn{6}{|c|}{$\mathbf{S A} / \mathbf{K}$} & \multicolumn{6}{|c|}{$\mathbf{S A} / \mathbf{S}$} \\
\hline & & 10.1 & 10.3 & 10.4 & 11.1 & 11.2 & 11.4 & 6.1 & 6.2 & 6.3 & 7.1 & 7.2 & 7.3 \\
\hline \multicolumn{2}{|l|}{ Ratkaisuosuus (\%) } & 81,6 & 46,3 & 69,3 & 84,1 & 68,8 & 80,4 & 70,2 & 96,8 & 94,7 & 54,3 & 67,0 & 74,5 \\
\hline \multicolumn{2}{|c|}{ Korrelaatio kuullun ymmärtämiseen } & .388 & .303 & .521 & .477 & .442 & .318 & .326 & .289 & .460 & .232 & .500 & .482 \\
\hline \multicolumn{2}{|l|}{ Korrelaatio koko kokeeseen } & .356 & .228 & .521 & .452 & .395 & .306 & .263 & .287 & .447 & .199 & .393 & .463 \\
\hline \multirow{3}{*}{$\begin{array}{l}\text { Merkitsevä ero sukupuolten } \\
\text { välillä }\end{array}$} & $\mathrm{t}$ & .414 & -1.374 & .955 & .291 & 1.002 & -1.945 & 1.107 & 1.026 & 1.344 & .934 & 1.468 & .069 \\
\hline & $\mathrm{df}$ & 389 & 389 & 388 & 389 & 389 & 388 & 92 & 92 & 92 & 92 & 92 & 92 \\
\hline & $\mathrm{p}$ & .679 & .170 & .340 & .771 & .317 & .053 & .271 & .308 & .182 & .353 & .146 & .946 \\
\hline \multirow{3}{*}{$\begin{array}{l}\text { Merkitsevä ero } \\
\text { opetuskielten välillä }\end{array}$} & $\mathrm{t}$ & -1.179 & 1.293 & \begin{tabular}{|l|}
-2.659 \\
\end{tabular} & -1.689 & -1.016 & \begin{tabular}{|l|}
-.603 \\
\end{tabular} & .626 & -.257 & -.335 & .121 & \begin{tabular}{|l|}
-.997 \\
\end{tabular} & -.831 \\
\hline & $\mathrm{df}$ & 389 & 389 & 388 & 389 & 389 & 388 & 92 & 92 & 92 & 92 & 92 & 92 \\
\hline & $\mathrm{p}$ & .239 & .197 & $.008^{* *}$ & .092 & .310 & .547 & .533 & \begin{tabular}{|l|}
.798 \\
\end{tabular} & .738 & .904 & .321 & .408 \\
\hline \multirow{3}{*}{$\begin{array}{l}\text { Merkitsevä ero alueiden } \\
\text { välillä }\end{array}$} & $\mathrm{F}$ & 1.020 & 2.756 & \begin{tabular}{|l|}
1.847 \\
\end{tabular} & 1.876 & .305 & .500 & .218 & .444 & .305 & .915 & 1.814 & 1.183 \\
\hline & $\mathrm{df}$ & 6 & 6 & 6 & 6 & 6 & 6 & 4 & 4 & 4 & 4 & 4 & 4 \\
\hline & $\mathrm{p}$ & .412 & $.012 *$ & .089 & .084 & .934 & .808 & .928 & .777 & .874 & .459 & .133 & .324 \\
\hline
\end{tabular}

\section{Videoon perustuvissa avoimissa osioissa vaaditut kompetenssit ja strategiat}

Kuvaamme seuraavaksi tehtäviä, joissa äänitteenä oli video ja tehtävätyyppinä avoimet kysymykset. Ne esitettiin kaikkien kielten tutkimusaineistossa koulun opetuskielellä, jolla niihin myös vastattiin. Englannin ylioppilaskokeissa (Abitreenit, 2018ab) tätä tehtävätyyppiä ei käytetty. Aineiston videotehtäviin liittyi useimmiten myös monivalintaosioita lukuun ottamatta ruotsin kevään koetta (Abitreenit, 2018c). 


\section{Ainedidaktiikka 5(1) (2021)}

Ruotsin kevään kokeessa Lund-tehtävän avoimien kysymysten (osiot 7.1-7.8) ratkaisu edellytti etenkin tärkeiden yksityiskohtien ja esimerkkien ymmärtämistä ja näiden poimimista oikeasta kohtaa videolta, sillä videota sai katsoa rajattomasti, ja videon kuvakulma vaihtui yli 40 kertaa. Vauhdikkaasti vaihtuvat kuvakulmat ja taustamusiikki tekivät nopeatempoisen vaikutelman. Videossa vilahti paikoitellen myös tekstiä ("Varför Lunds universitet?"). Lisäksi puhujien nimet ja koulutusalat esiteltiin tekstinä aina puhujan vaihtuessa, joten tehtävän ratkaiseminen edellytti multimodaalista tulkintaa.

Ruotsin syksyn kokeessa tehtävään 7 (Barnens Finland) liittyi edellisessä luvussa esiteltyjen monivalintojen lisäksi kaksi avointa kysymystä. Osion 7.4 ratkaiseminen edellytti pääajatusta tukevien yksityiskohtien ymmärtämistä. Osio 7.5 (Millä tavoin kuritus on muuttunut 1980luvulta nykypäiviin?) vaati päättelyä videokatkelman perusteella. Kielellisen sisällön lisäksi osio 7.5 pohjautui videolla nähtävän infograafin tulkintaan. Keskeisen sanaston (ru. aga, 'kuritus') hallitseminen tai vaihtoehtoisesti kyky kompensoida puuttuvan sanavaraston esimerkiksi päättelemällä tuntemattomien sanojen merkitys muun tekstin avulla helpotti oikean kohdan löytämistä videolta.

Saksan kevään kokeessa käytettiin videota aineistona kahdessa avoimessa tehtävässä (10 Sängerknaben, 11 Kartoffeln). Osioiden 10.2 ja11.3 ratkaiseminen edellytti yksityiskohdan ymmärtämistä. Jälkimmäisessä videolla näytettävän animaation seuraaminen ja kuvan tulkinta helpottivat vastaamista.

Saksan syksyn kokeessa kumpaankin videotehtävään liittyi avoin kysymys. Molemmissa haettiin kuullun katkelman pääajatuksen ymmärtämistä ja multimodaalista tulkintaa, jota kuvattiin tarkemmin edellisessä luvussa.

Seuraavassa taulukossa (Taulukko 7) on yhteenveto avoimista kysymyksistä, jotka perustuvat videoon.

\section{Taulukko 7. Videoon perustuvat avoimet kysymykset}

\begin{tabular}{|c|c|c|c|}
\hline $\begin{array}{l}\text { Koe / tehtävä, } \\
\text { (videoon perus- } \\
\text { tuvat avoimet } \\
\text { kysymykset) }\end{array}$ & $\begin{array}{l}\text { Tehtävän ai- } \\
\text { neisto, äänit- } \\
\text { teen kesto, } \\
\text { kuunteluker- } \\
\text { rat, lähteet }\end{array}$ & $\begin{array}{l}\text { Tekstityyppi, kurssit, } \\
\text { aihepiirit, puhenopeus, } \\
\text { taitotaso (jaos), abst- } \\
\text { raktiotaso, sanaston ja } \\
\text { rakenteiden vaativuus }\end{array}$ & $\begin{array}{l}\text { Tutkittujen osioiden rat- } \\
\text { kaisussa tarvittavat kom- } \\
\text { petenssit ja strategiat } \\
\text { (TK1) }\end{array}$ \\
\hline $\begin{array}{l}\text { Ruotsi, kevät } \\
7 \text { Att studera i } \\
\text { Lund } \\
\text { (osiot } 7.1-7.8 \text { ) }\end{array}$ & $\begin{array}{l}\text { Video 2:26 } \\
\text { Rajaton } \\
\text { Youtube }\end{array}$ & $\begin{array}{l}\text { Kuvaileva, kertova } \\
6 \\
\text { Opiskelu } \\
\text { Normaal } \\
\text { B1.2 } \\
\text { Pääasiassa yksinker- } \\
\text { taista } \\
\text { Pääasiassa konkreettinen }\end{array}$ & $\begin{array}{l}\text { Multimodaalinen tulkinta } \\
\text { (video, teksti) } \\
\text { Tärkeiden yksityiskohtien } \\
\text { ja esimerkkien ymmärtämi- } \\
\text { nen (8) }\end{array}$ \\
\hline $\begin{array}{l}\text { Ruotsi, syksy } \\
7 \text { Barnens } \\
\text { Finland } \\
\text { (osiot } 7.4,7.5 \text { ) }\end{array}$ & $\begin{array}{l}\text { Video 2:37 } \\
\text { Rajaton } \\
\text { Youtube }\end{array}$ & $\begin{array}{l}\text { Kuvaileva, kertova } \\
4 \\
\text { Historia } \\
\text { Normaali } \\
\text { B2.1 } \\
\text { Pääasiassa konkreettinen } \\
\text { Jossakin määrin vaativa }\end{array}$ & $\begin{array}{l}\text { Multimodaalinen tulkinta } \\
\text { (video, infograafi, teksti, } \\
\text { kuvat) } \\
\text { Pääajatusta tukevan yksi- } \\
\text { tyiskohdan ymmärtäminen; } \\
\text { Johtopäätöksen tekeminen, } \\
\text { kuvan tulkinta }\end{array}$ \\
\hline
\end{tabular}


Ainedidaktiikka 5(1) (2021)

\begin{tabular}{|c|c|c|c|}
\hline $\begin{array}{l}\text { Saksa, kevät } \\
10 \text { Sängerknaben } \\
\text { (osio 10.2) }\end{array}$ & $\begin{array}{l}\text { Video 3:39 } \\
\text { Rajaton } \\
\text { Youtube }\end{array}$ & $\begin{array}{l}\text { Kertova, kuvaileva } \\
3 \\
\text { Musiikki } \\
\text { Normaali } \\
\text { B1.2-B2.1 } \\
\text { Konkreettinen } \\
\text { Jossakin määrin vaativa }\end{array}$ & $\begin{array}{l}\text { Yksityiskohdan ymmärtä- } \\
\text { minen }\end{array}$ \\
\hline $\begin{array}{l}\text { Saksa, kevät } \\
11 \text { Kartoffeln } \\
\text { (osio 11.3) }\end{array}$ & $\begin{array}{l}\text { Video 2:38 } \\
\text { Rajaton } \\
\text { Youtube }\end{array}$ & $\begin{array}{l}\text { Kertova, kuvaileva } \\
4 \\
\text { Historia } \\
\text { Normaali } \\
\text { B1.2-B2.2 } \\
\text { Konkreettinen } \\
\text { Jossakin määrin vaativa }\end{array}$ & $\begin{array}{l}\text { Multimodaalinen tulkinta } \\
\text { (video, kuvat) } \\
\text { Yksityiskohdan ymmärtä- } \\
\text { minen }\end{array}$ \\
\hline $\begin{array}{l}\text { Saksa, syksy } \\
6 \text { Melanie Mühl } \\
\text { (osio 6.4) }\end{array}$ & $\begin{array}{l}\text { Video 2:54 } \\
\text { Rajaton } \\
\text { Youtube }\end{array}$ & $\begin{array}{l}\text { Kertova } \\
5,8 \\
\text { Tieteenalat } \\
\text { Nopea } \\
\text { B1.2-B2.2 } \\
\text { Pääasiassa konkreettinen } \\
\text { Jossakin määrin vaati- } \\
\text { vaa / Erittäin vaativa }\end{array}$ & $\begin{array}{l}\text { Multimodaalinen tulkinta } \\
\text { (video, tekstit) } \\
\text { Pääajatuksen ymmärtämi- } \\
\text { nen }\end{array}$ \\
\hline $\begin{array}{l}\text { Saksa, syksy } \\
7 \text { Erfinder } \\
\text { (osio 7.4) }\end{array}$ & $\begin{array}{l}\text { Video 2:22 } \\
\text { Rajaton } \\
\text { Youtube }\end{array}$ & $\begin{array}{l}\text { Kertova } \\
4,5 \\
\text { Luova toiminta } \\
\text { Normaali } \\
\text { B1.2-B2.1 } \\
\text { Pääasiassa konkreettinen } \\
\text { Jossakin määrin vaati- } \\
\text { vaa / Erittäin vaativa }\end{array}$ & $\begin{array}{l}\text { Multimodaalinen tulkinta } \\
\text { (video, kuvat) } \\
\text { Pääajatuksen ymmärtämi- } \\
\text { nen }\end{array}$ \\
\hline $\begin{array}{l}\text { Ruotsi, kevät } \\
7 \text { Att studera i } \\
\text { Lund } \\
(\text { osiot } 7.1-7.8)\end{array}$ & $\begin{array}{l}\text { Video 2:26 } \\
\text { Rajaton } \\
\text { Youtube }\end{array}$ & $\begin{array}{l}\text { Kuvaileva, kertova } \\
6 \\
\text { Opiskelu } \\
\text { Normaali } \\
\text { B1.2 } \\
\text { Pääasiassa yksinker- } \\
\text { taista } \\
\text { Pääasiassa konkreettinen }\end{array}$ & $\begin{array}{l}\text { Multimodaalinen tulkinta } \\
\text { (video, teksti) } \\
\text { Tärkeiden yksityiskohtien } \\
\text { ja esimerkkien ymmärtämi- } \\
\text { nen (8) }\end{array}$ \\
\hline $\begin{array}{l}\text { Ruotsi, syksy } \\
7 \text { Barnens } \\
\text { Finland } \\
\text { (osiot } 7.4,7.5 \text { ) }\end{array}$ & $\begin{array}{l}\text { Video 2:37 } \\
\text { Rajaton } \\
\text { Youtube }\end{array}$ & $\begin{array}{l}\text { Kuvaileva, kertova } \\
4 \\
\text { Historia } \\
\text { Normaali } \\
\text { B2.1 } \\
\text { Pääasiassa konkreettinen } \\
\text { Jossakin määrin vaativa }\end{array}$ & $\begin{array}{l}\text { Multimodaalinen tulkinta } \\
\text { (video, infograafi, teksti, } \\
\text { kuvat) } \\
\text { Pääajatusta tukevan yksi- } \\
\text { tyiskohdan ymmärtäminen; } \\
\text { Johtopäätöksen tekeminen, } \\
\text { kuvan tulkinta }\end{array}$ \\
\hline $\begin{array}{l}\text { Saksa, kevät } \\
10 \text { Sängerknaben } \\
\text { (osio 10.2) }\end{array}$ & $\begin{array}{l}\text { Video 3:39 } \\
\text { Rajaton } \\
\text { Youtube }\end{array}$ & $\begin{array}{l}\text { Kertova, kuvaileva } \\
3 \\
\text { Musiikki } \\
\text { Normaali } \\
\text { B1.2-B2.1 } \\
\text { Konkreettinen } \\
\text { Jossakin määrin vaativa }\end{array}$ & $\begin{array}{l}\text { Yksityiskohdan ymmärtä- } \\
\text { minen }\end{array}$ \\
\hline $\begin{array}{l}\text { Saksa, kevät } \\
11 \text { Kartoffeln } \\
\text { (osio 11.3) }\end{array}$ & $\begin{array}{l}\text { Video 2:38 } \\
\text { Rajaton } \\
\text { Youtube }\end{array}$ & $\begin{array}{l}\text { Kertova, kuvaileva } \\
4 \\
\text { Historia } \\
\text { Normaali } \\
\text { B1.2-B2.2 } \\
\text { Konkreettinen } \\
\text { Jossakin määrin vaativa }\end{array}$ & $\begin{array}{l}\text { Multimodaalinen tulkinta } \\
\text { (video, kuvat) } \\
\text { Yksityiskohdan ymmärtä- } \\
\text { minen }\end{array}$ \\
\hline
\end{tabular}

Seuraavaan taulukkoon (Taulukko 8) on koottu osioiden ratkaisuosuudet, korrelaatiot ja merkitsevät erot toisen tutkimuskysymyksen eli reiluuden 
toteutumisen kannalta. Avo-osioiden ratkaisuosuudet jakaantuivat kahtia riippuen siitä, saiko kokelas kyseisestä osiosta täydet pisteet vai vain osan pisteistä. Korrelaatiot koko kuullunymmärtämistaitoon olivat keskimäärin korkeampia kuin videomonivalintaosioiden korrelaatiot tähän osataitoon.

Taulukko 8. Videoon perustuvien avoimien kysymysten ratkaisuosuudet ja korrelaatiot

\begin{tabular}{|c|c|c|c|c|c|c|c|c|c|c|c|c|c|c|c|}
\hline \multirow{2}{*}{\multicolumn{2}{|c|}{$\begin{array}{l}\text { Koe } \\
\text { Osio }\end{array}$}} & \multicolumn{8}{|c|}{ RU/K } & \multicolumn{2}{|c|}{$\mathbf{R U} / \mathbf{S}$} & \multicolumn{2}{|c|}{ SA/K } & \multicolumn{2}{|c|}{$\mathbf{S A} / \mathbf{S}$} \\
\hline & & 7.1 & 7.2 & 7.3 & 7.4 & 7.5 & 7.6 & 7.7 & 7.8 & 7.4 & 7.5 & 10.2 & 11.3 & 6.4 & 7.4 \\
\hline \multicolumn{2}{|c|}{\begin{tabular}{|l|} 
Ratkaisuosuus (\%), \\
täydet pisteet
\end{tabular}} & 25,2 & 10,0 & 78,0 & 73,3 & 49,1 & 58,3 & 28,0 & 36,7 & 38,7 & 48,3 & 54,6 & 60,7 & 28,0 & 25,5 \\
\hline \multicolumn{2}{|c|}{\begin{tabular}{|l|} 
Ratkaisuosuus (\%), \\
osa pisteistä
\end{tabular}} & 49,4 & 84,0 & 19,5 & 21,9 & 31,1 & 3,5 & 38,3 & 6,5 & 49,4 & 31,9 & 0,3 & . & 69,9 & 66,0 \\
\hline \multicolumn{2}{|c|}{\begin{tabular}{|l|} 
Korrelaatio kuullun \\
ymmärtämiseen
\end{tabular}} & .592 & .361 & .403 & .504 & .627 & .585 & .629 & .457 & .551 & .476 & .572 & .553 & .422 & .633 \\
\hline \multicolumn{2}{|c|}{$\begin{array}{l}\text { Korrelaatio koko } \\
\text { kokeeseen }\end{array}$} & \begin{tabular}{l|}
.600 \\
\end{tabular} & .378 & .429 & .500 & .634 & .568 & .615 & .474 & .555 & .447 & .552 & .522 & .373 & .563 \\
\hline \multirow{3}{*}{$\begin{array}{l}\text { Merkitsevä ero } \\
\text { sukupuolten } \\
\text { välillä }\end{array}$} & $t$ & .027 & -.167 & 1.553 & -1.416 & 2.848 & -.464 & 1.318 & -.522 & .706 & \begin{tabular}{|l|}
2.657 \\
\end{tabular} & .215 & 1.632 & 2.399 & 2.110 \\
\hline & $\mathrm{df}$ & 1047 & 1054 & 1056 & 1056 & 1054 & 1054 & 1038 & 1033 & 543 & 543 & 386 & 387 & 91 & 92 \\
\hline & $\mathrm{p}$ & .978 & .867 & .121 & .157 & $.004^{* *}$ & .643 & .188 & .602 & .481 & $.008^{* *}$ & .830 & .104 & \begin{tabular}{|l|}
$.018^{*}$ \\
\end{tabular} & $.038^{*}$ \\
\hline \multirow{3}{*}{$\begin{array}{l}\text { Merkitsevä ero } \\
\text { opetuskielten } \\
\text { välillä }\end{array}$} & $\mathrm{t}$ & . & . & . & . & . & . & . & . & $\cdot$ & . & -2.180 & -1.723 & -2.225 & -2.155 \\
\hline & $\mathrm{df}$ & . & . & . & . & . & . & . & . & . & . & 386 & 387 & 91 & 92 \\
\hline & $\mathrm{p}$ & . & . & . & . & . & . & . & . & . & . & \begin{tabular}{|l|}
$.030^{*}$ \\
\end{tabular} & .086 & \begin{tabular}{|l|}
$.029^{*}$ \\
\end{tabular} & $.034 *$ \\
\hline \multirow{3}{*}{\begin{tabular}{|l|} 
Merkitsevä ero \\
alueiden välillä
\end{tabular}} & $\mathrm{F}$ & 3.654 & 9.538 & 10.844 & 3.923 & 12.283 & 8.801 & 7.571 & 3.145 & 5.970 & 3.210 & 1.532 & 1.765 & 1.420 & .729 \\
\hline & $\mathrm{df}$ & 5 & 5 & 5 & 5 & 5 & 5 & 5 & 5 & 5 & 5 & 6 & 6 & 4 & 4 \\
\hline & $p$ & $.003 * *$ & $.000^{* * *}$ & $.000^{* * *}$ & $.002 * *$ & $.000^{* * *}$ & $.000^{* * *}$ & $.000^{* * *}$ & $.008^{* *}$ & $.000^{* * *}$ & $.007 * *$ & .166 & .105 & .234 & .574 \\
\hline
\end{tabular}

Videoon perustuvien avoimien osioiden keskiarvot poikkesivat merkitsevästi toisistaan tyttöjen ja poikien välillä ainoastaan ruotsin kevään (Abitreenit, 2018c) osiossa 7.5 ja syksyn osiossa 7.5. Pojat pärjäsivät tyttöjä paremmin molemmissa osioissa. Eri alueiden välillä merkitseviä eroja oli ruotsin kokeissa tutkituissa osioissa paljon. Kevään kokeessa erityisesti Lappi ja Etelä-Suomi pärjäsivät niissä hyvin. Etelä-Suomi suoriutui hyvin tutkituissa osioissa myös syksyn kokeessa. Alueista heikoimmin menestyttiin tutkituissa osioissa Itä- ja Pohjois-Suomessa. Saksan kokeissa ei ilmennyt merkitseviä eroja alueiden välillä mitä tulee tutkittuihin osioihin.

\section{Audioon perustuvissa monivalintaosioissa vaaditut kompetenssit ja strategiat}

Kuvaamme seuraavaksi kahta englannin syksyn kokeessa (Abitreenit, 2018b) esiintynyttä monivalintatehtävää, joissa varsinaisen äänitteen lisäksi oli hyödynnetty audiota monivalintakysymysten vastausvaihtoehtoina (audiomonivalintaosio tai -tehtävä). Aineiston muissa kokeissa kyseistä tehtävätyyppiä ei esiintynyt.

Englannin syksyn kokeessa kahdessa tehtävässä (tehtävä 6 Bookshop Phone Call, tehtävä 7 Bad Mood Conversation) monivalintatehtävän vastausvaihtoehdot kuultiin äänitteinä, minkä lisäksi ne esitettiin tekstinä. Kummassakin tehtävässä oli kaksi osiota, jossa kysymykseen oli annettu neljä vastausvaihtoehtoa. Molemmissa tehtävissä edellytettiin kykyä eläytyä keskustelutilanteeseen sekä valita annetuista vaihtoehdoista 
kohteliain ja tilanteeseen sopivin (osiot 6.1, 6.2) tai epäkohteliain ja huonoiten sopiva (osiot 7.1, 7.2) repliikki keskustelun jatkoksi.

Seuraavassa taulukossa (Taulukko 9) esitetään yhteenveto näistä tehtävistä.

\section{Taulukko 9. Audio monivalintaosioiden vaihtoehdoissa}

\begin{tabular}{|c|c|c|c|}
\hline $\begin{array}{l}\text { Koe / tehtävä, } \\
\text { (audiomoni- } \\
\text { valintaosiot) }\end{array}$ & $\begin{array}{l}\text { Tehtävän ai- } \\
\text { neisto, äänit- } \\
\text { teen kesto, } \\
\text { kuunteluker- } \\
\text { rat, lähteet }\end{array}$ & $\begin{array}{l}\text { Tekstityyppi, kurssit, } \\
\text { aihepiirit, puhenopeus, } \\
\text { taitotaso (jaos), abst- } \\
\text { raktiotaso, sanaston ja } \\
\text { rakenteiden vaativuus }\end{array}$ & $\begin{array}{l}\text { Tutkittujen osioiden rat- } \\
\text { kaisussa tarvittavat kom- } \\
\text { petenssit ja strategiat } \\
\text { (TK1) }\end{array}$ \\
\hline $\begin{array}{l}\text { Englanti, syksy } \\
6 \text { Bookshop } \\
\text { Phone Call } \\
\text { (osiot } 6.1,6.2)\end{array}$ & $\begin{array}{l}2 \mathrm{x} \text { audio á } \\
0: 21 \\
8 \mathrm{x} \text { audio á } \\
0: 02-0: 03 \\
\text { 2krt / vaihtoeh- } \\
\text { dot rajaton } \\
\text { YTL }\end{array}$ & $\begin{array}{l}\text { Kertova } \\
3 \\
\text { Kirjallisuus } \\
\text { Normaali } \\
\text { B1.1 } \\
\text { Konkreettinen } \\
\text { Pääasiassa yksinkertai- } \\
\text { nen }\end{array}$ & $\begin{array}{l}\text { Pragmaattiset kompetenssit } \\
\text { (skeema- ja diskurssikom- } \\
\text { petenssi) } \\
\text { Sopivan jatkon päättely }\end{array}$ \\
\hline $\begin{array}{l}\text { Englanti, syksy } \\
7 \text { Bad Mood } \\
\text { Conversation } \\
\text { (osiot } 7.1,7.2)\end{array}$ & $\begin{array}{l}2 \mathrm{x} \text { audio á } 0: 10 \\
8 \mathrm{x} \text { audio á } \\
0: 03-0: 04 \\
2 \mathrm{krt} / \text { vaihto- } \\
\text { ehdot rajaton } \\
\text { YTL }\end{array}$ & $\begin{array}{l}\text { Kertova } \\
1 \\
\text { Arkirutiinit } \\
\text { Normaali } \\
\text { B1.1 } \\
\text { Konkreettinen } \\
\text { Pääasiassa yksinkertai- } \\
\text { nen }\end{array}$ & $\begin{array}{l}\text { Pragmaattinen kompetenssi } \\
\text { (skeema- ja diskurssikom- } \\
\text { petenssit) } \\
\text { Sosiolingvistinen kompe- } \\
\text { tenssi (kohteliaisuuskon- } \\
\text { ventiot) } \\
\text { Sopivan jatkon päättely }\end{array}$ \\
\hline
\end{tabular}

Toiseen tutkimuskysymykseen liittyen tarkasteltiin audiomonivalintaosioiden ratkaisuosuuksia, korrelaatioita sekä merkitseviä eroja eri kokelasryhmien välillä. Kuten taulukosta (Taulukko 10) ilmenee, näiden osioiden ratkaisuosuudet vaihtelivat pienten ja keskisuurten välillä.

Tutkituissa osioissa esiintyi useita merkitseviä eroja sekä tyttöjen ja poikien että suomen- ja ruotsinkielisten kokelaiden välillä. Osiossa 6.2 tytöt menestyivät paremmin, kun taas osiossa 6.1 pojat päihittivät heidät. Ruotsinkieliset kokelaat menestyivät keskiarvojen perusteella suomenkielisiä paremmin kaikissa kolmessa osiossa, joissa ero oli merkitsevä tai melkein merkitsevä. Alueiden välillä erot olivat erittäin merkitseviä yhtä osiota lukuun ottamatta. Ahvenanmaa ja Etelä-Suomi menestyivät näissä hyvin, Itä- ja Pohjois-Suomi heikommin. 
Taulukko 10. Audiomonivalintaosioiden ratkaisuosuudet ja korrelaatiot

\begin{tabular}{|c|c|c|c|c|c|}
\hline \multicolumn{2}{|l|}{ Koe } & \multicolumn{4}{|c|}{$\mathbf{E N} / \mathbf{S}$} \\
\hline \multicolumn{2}{|l|}{ Osio } & 6.1 & 6.2 & 7.1 & 7.2 \\
\hline \multicolumn{2}{|l|}{ Ratkaisuosuus (\%) } & 44,0 & 83,0 & 48,3 & 65,8 \\
\hline \multicolumn{2}{|l|}{ Korrelaatio kuullun ymmärtämiseen } & .324 & .354 & .291 & .473 \\
\hline \multicolumn{2}{|l|}{ Korrelaatio koko kokeeseen } & .272 & .335 & .254 & .452 \\
\hline \multirow[t]{3}{*}{ Merkitsevä ero sukupuolten välillä } & $\mathrm{t}$ & 3.010 & -5.664 & 8.713 & 1.862 \\
\hline & $\mathrm{df}$ & 16848 & 16847 & 16855 & 16856 \\
\hline & $\mathrm{p}$ & $.003 * *$ & $.000 * * *$ & $.000 * * *$ & .063 \\
\hline \multirow[t]{3}{*}{ Merkitsevä ero opetuskielten välillä } & $\mathrm{t}$ & -7.832 & -8.762 & 1.831 & -2.317 \\
\hline & $\mathrm{df}$ & 16849 & 16848 & 16856 & 16857 \\
\hline & $\mathrm{p}$ & $.000 * * *$ & $.000 * * *$ & .067 & $.021^{*}$ \\
\hline \multirow[t]{3}{*}{ Merkitsevä ero alueiden välillä } & $\mathrm{F}$ & 10.768 & 11.670 & 1.220 & 14.127 \\
\hline & $\mathrm{df}$ & 6 & 6 & 6 & 6 \\
\hline & $\mathrm{p}$ & $.000 * * *$ & $.000 * * *$ & .292 & $.000 * * *$ \\
\hline \multicolumn{6}{|l|}{$\begin{array}{l}\text { *. Ero on merkitsevä } 0.05 \text {-tasolla } \\
* * \text {. Ero on merkitsevä } 0.01 \text {-tasolla } \\
* * * \text {. Ero on merkitsevä } 0.001 \text {-tasolla } \\
\text { EN = englanti, } \mathrm{S}=\text { syksy }\end{array}$} \\
\hline
\end{tabular}

\section{Yhteenveto tehtävissä vaadituista kompetensseista ja strategioista ja niiden reiluudesta}

Ensimmäisessä tutkimuskysymyksessä kartoitettiin multimodaalisten tehtävien vaatimia kompetensseja ja strategioita, joilla kompetenssiin kuuluva taito pannaan täytäntöön. Tavallisimmin edellytettiin yksityiskohdan ymmärtämistä sekä jonkin verran pääkohdan tai kokonaisajatuksen hahmottamista. Multimodaalisen aineiston kokonaistulkinta korostui videota ja kuvia sisältävissä koetehtävissä. Vain harvoin edellytettiin julkilausumattoman johtopäätöksen tekoa. Eritasoiset päättelystrategiat olivat kokelaille hyödyksi, mutta useimmiten vaadittiin sanapäättelyä leksikaalisen kompetenssin tueksi. Muutamissa englannin osioissa painottuvat pragmaattiset ja sosiolingvistiset taidot.

Toinen tutkimuskysymys koski multimodaalisten osioiden reiluutta tasa-arvon ja näkökulmasta. Sukupuolten välisiä eroja esiintyi jonkin verran englannin ja ruotsin kielissä: englannissa poikien ja ruotsissa tyttöjen eduksi. Koulun opetuskielen mukaisia eroja ruotsinkielisten koulujen hyväksi havaittiin englannissa. Sekä englannissa että ruotsissa maan eteläosien kokelaat menestyivät pohjoisen ja itäisten alueiden kokelaita paremmin. Saksa osoittautui tutkituista kielistä tasavertaisimmaksi, sillä siinä kaikki tutkitut erot olivat pieniä. Kuvamonivalinta oli kaikissa kielissä kokelaille selkeästi helpoin, sillä ratkaisuosuudet näissä osioissa olivat erittäin korkeat. Multimodaalisia tehtävätyyppejä edustavien osioiden korrelaatiot muihin kuuntelutaitoa mitanneisiin osioihin ja koko kokeeseen vaihtelivat pienistä keskisuuriin. 


\section{Pohdinta}

Tutkimuksessa paneuduttiin siihen, miten tarkoituksenmukaisesti ja tasavertaisesti ylioppilastutkinnon kielikokeiden multimodaaliset osiot mittasivat englannin, ruotsin ja saksan kielen taitoa. Alkuvaiheessa tehtävien laadinta on ollut kokeilevaa, koska tutkimustieto erityyppisten osioiden toimivuudesta ja tilastollisista ominaisuuksista on peräisin muualta kuin suomalaisen yleissivistävän koulutuksen kontekstista ja siten rajallisesti siihen sovellettavissa.

Tutkimamme digitaaliset koetehtävät myötäilivät hyvin lukion uudempien opetussuunnitelmaperusteiden (Opetushallitus, 2015, s. 38) multimodaalista tekstikäsitystä sekä opetuksen tavoitteena olevaa monilukutaitoa. Niissä toteutui laaja-alainen tekstikäsitys, jonka mukaan "tekstit ovat sanallisten, kuvallisten, auditiivisten, numeeristen ja kinesteettisten symbolijärjestelmien ja niiden yhdistelmien muodostamia kokonaisuuksia" (Opetushallitus, 2015, s. 38).

Tutkittujen koeosioiden ratkaisuun vaadittavat kompetenssit ja strategiat vastasivat tarkoituksenmukaisesti lukion opetussuunnitelman perusteissa asetettuja tavoitteita. Taito tulkita puhuttuja tekstejä ulottuu Kehittyvän kielitaidon tasojen kuvausasteikon mukaan keskimäärin tasoille B1.2 - B2.1, joilla vaativahkostakin tekstistä pystytään erottamaan pääasiat ja yksityiskohdat ja tekemään yhä kehittyneempiä päätelmiä. Näitä tutkitut osiot kohtuullisen johdonmukaisesti mittasivat. Tarkempi analyysi edellyttäisi tasoarvioiden tarkistamista ja verrannustutkimusta.

Digitaalinen koeformaatti haastaa perinteisen kuullun ymmärtämisen käsitteen yksinomaan kielellisen auditiivisen puheen ymmärtämisenä ja siihen reagointina. Aiemmin hyvään suoriutumiseen riittivät lähinnä kielelliset kompetenssit ja erilaiset päättelystrategiat. Kielellisten viestintäkompetenssien pragmaattisten ja sosiolingvististen tietojen ja taitojen osuus oli varsin vähäinen, samoin kulttuurien tuntemus yleisten kompetenssien saralta. Multimodaaliseen aineistoon perustuvat tehtävät puolestaan edellyttävät näitä entistä useammin, kun ratkaisu saattaa edellyttää useamman ilmaisumuodon samanaikaista tulkitsemista sekä tarvittavan tiedon (ks. Buck, 2001, s. 129-130) suodattamista eri informaatiolähteistä, mikä voi olla kognitiivisesti kuormittavaa (Buck, 2001, s. 254; von Zansen, 2019, s. 187). Lisäksi myös muiden oppiaineiden kautta saavutettu laaja-alainen osaaminen (Opetushallitus, 2015, 2019) on mahdollista tavoittaa entistä paremmin, kun ymmärtämisen kohteena on pelkän studiotallennetun audiosignaalin rinnalla ja sijasta arkielämän tarkoituksiin laadittua kuvaa, ääntä ja eri tieteenaloihin ja kulttuureihin liittyviä symboleja. Aineistossa esiintyvien kuuntelutehtävien videot liittyivät usein taiteeseen, musiikkiin tai historiaan. Videoaineistojen tekstityyppi oli useimmiten kuvaileva tai kertova, kun taas pohtivia ja argumentoivia videoaineistoja käytettiin niukemmin. Olisikin tarpeellista huolehtia koeaineistojen monipuolisuudesta, sillä isojen ja tärkeiden kokeiden tehtävillä on takaistusvaikutusta myös harjoittelu- ja opetuskäytänteisiin (Buck, 2001, s. 196). 
Reiluus toteutuu uusissa tehtävätyypeissä melko hyvin, sillä tutkitussa aineistossa ilmeni merkitseviä eroja eri kokelasryhmien välillä ainoastaan yksittäisissä osioissa. Alueiden välillä eroja oli enemmän kuin sukupuolten tai opetuskielten välillä. Sukupuolten ja opetuskielten välisiä eroja ilmeni eniten englannin video- ja audiomonivalintaosioissa, joissa ruotsinkieliset kokelaat menestyivät suomenkielisiä paremmin ja pojat pääasiassa tyttöjä paremmin. Englannin ja ruotsin osalta tulokset myötäilevät perusopetuksen päättyessä tehtyjä oppimistulosarviointeja pitkissä oppimäärissä (Härmälä, Huhtanen \& Puukko, 2014; Hildén \& Rautopuro, 2014a) sekä aiempia tutkimustuloksia sukupuolten menestymiseroista keskipitkän ruotsin ylioppilaskokeissa (Juurakko-Paavola, 2016). Lisää tutkimusta pitäisi suunnata muiden kuin englannin kielen pitkän oppimäärän kokelasjoukon koostumukseen pitemmällä aikavälillä. Perusopetuksen oppimistulosarviointien valossa harvemmin opiskeltujen kielten oppimääriä valitsevat useammin kuin englantia sellaiset oppilaat, joiden vanhemmilla on ylioppilastutkinto. Tämä pätee myös saksan pitkän oppimäärän valintoihin (Hildén \& Rautopuro, 2014b, s. 71; Härmälä, Huhtanen \& Puukko, 2014, s. 38). Samat taustaerot pysyvät ja vaikuttavat luonnollisesti myös lukion päättövaiheen tuloksiin, mikä saattaa osaltaan selittää saksan tehtävissä nyt havaittua vähäistä vaihtelua kokelasjoukon homogeenisuudesta johtuvaksi.

Kaikkien kokelaiden kesken ratkaisuosuudet olivat kuvamonivalintaosioissa korkeita sekä pitkän ruotsin, englannin että saksan ylioppilaskokeissa keväällä vuonna 2018. Video- ja audiomonivalintaosioiden ratkaisuosuuksissa vaihtelua esiintyi enemmän kuin kuvamonivalintaosioissa. Tehtävien laatijoiden haasteena on riittävän vaativien ja erottelukykyisten kuvamonivalintojen keksiminen. Lisätutkimusta kaivataan myös videotehtävien osuvuuden ja yksiselitteisyyden varmistamiseen.

Tutkimuksen luotettavuuden kannalta ongelmalliseksi osoittautui kielijaosten tuottama tehtävien kuvausaineisto, jonka olisi tarkoitus antaa perustiedot kunkin osion mittaamasta tekstityypistä, kieliaineksen vaativuudesta ja päättelyn tasosta. Kuvauslomakkeiden tieto oli kuitenkin epätasaista ja paikoin puutteellista. Tutkijat joutuivat tekemään nämä luokitukset uudelleen vastoin alkuperäistä suunnitelmaa. Kuvauslomakkeiden puutteet ovat jossain määrin ymmärrettäviä, koska kokeenlaatijat eivät ole tutkijoita eikä Ylioppilastutkintolautakunta tieteellinen toimija. Tutkinnon on kuitenkin myös vastaisuudessa perustuttava tieteelliseen tietoon, jonka tuottamiseen on toivottavaa olla helppokäyttöinen tapa kerätä perustiedot kunkin koekerran tehtävistä ja osioista tutkimusta ja jatkojalostusta varten. Digitaalinen tutkinto mahdollistaakin systemaattisen tiedonkeruun entistä vaivattomammin.

Reiluudesta ja oikeudenmukaisuudesta tämä tutkimus antoi vasta hyvin alustavaa tietoa. Vastedes osioiden ominaisuuksia on tarkasteltava myös muiden reiluusperiaatteiden, kuten koejärjestelyjen ja arvosanojen sisäisen ryhmävaihtelun kannalta. Etenkin erottelukyvyn mahdollisiin vinoumiin yhtä hyvin menestyneiden kokelassegmenttien sisällä on syytä kiinnittää huomiota ja analysoida niitä esimerkiksi differential item functioning eli DIF-analyysillä (esim. Ferne \& Rupp, 2007).

Osioiden tehtävänannoissa edellytettyjen kompetenssien ja strategioiden lisäksi tulisi tutkia myös sitä, mitä näistä kokelaat todella käyttivät 


\section{Ainedidaktiikka 5(1) (2021)}

ratkaistessaan osiota ja päätyessään antamaansa - oikeaan tai virheelliseen - vastaukseen. Tämä vaatii laadullista tutkimusotetta yksilötasolla. Kun multimodaaliset tehtävätyypit vakiintuvat ja niistä karttuu aineistoa, myös säännöllinen vertailu opetussuunnitelmaan on paikallaan. Onhan lukion opetussuunnitelman toteutumisen mittaaminen ylioppilastutkinnon ydintehtävä.

\section{Lähteet}

\section{Aineistolähteet}

Abitreenit (2018a). Pitkän englannin kevään 2018 ylioppilaskoe. Haettu 7.8.2020 osoitteesta http://yle.fi/plus/abitreenit/2018/kevat/EA-fi/EA-fi/index.html

Abitreenit (2018b). Pitkän englannin syksyn 2018 ylioppilaskoe. Haettu 7.8.2020 osoitteesta https://yle.fi/plus/abitreenit/2018/syksy/EA-fi/

Abitreenit (2018c). Pitkän ruotsin kevään 2018 ylioppilaskoe. Haettu 7.8.2020 osoitteesta http://yle.fi/plus/abitreenit/2018/kevat/BA-fi/BA-fi/index.html

Abitreenit (2018d). Pitkän ruotsin syksyn 2018 ylioppilaskoe. Haettu 7.8.2020 osoitteesta https://yle.fi/plus/abitreenit/2018/syksy/BA-fi/

Abitreenit (2018e). Pitkän saksan kevään 2018 ylioppilaskoe. Haettu 7.8.2020 osoitteesta http://yle.fi/plus/abitreenit/2018/kevat/SA-fi/SA-fi/index.html

Abitreenit (2018f). Pitkän saksan syksyn 2018 ylioppilaskoe. Haettu 7.8.2020 osoitteesta https://yle.fi/plus/abitreenit/2018/syksy/SA-fi/

Abitreenit (n.d.). Ylen Abitreenit -verkkosivusto. Haettu 25.6.2020 osoitteesta https://yle.fi/aihe/abitreenit

\section{Tutkimuslähteet}

Anckar, J. (2011). Assessing foreign language listening comprehension by means of the multiple-choice format: Processes and products. (Väitöskirja). Jyväskylän yliopisto. http://urn.fi/URN:ISBN:978-951-39-4410-0

Bachman, L. \& Palmer, A. (1996). Language Testing in Practice. Oxford: Oxford University Press.

Bachman, L. \& Palmer, A. (2010). Language assessment in practice: Developing language assessments and justifying their use in the real world. Oxford: Oxford University Press.

Buck, G. (2001). Assessing Listening. Cambridge: Cambridge University Press. https://doi.org/10.1017/CBO9780511732959

EVK (2003). Eurooppalainen viitekehys. Kielten oppimisen, opettamisen ja arvioinnin yhteinen eurooppalainen viitekehys. Suom. I. Huttunen ja H. Jaakkola. WSOY: Helsinki.

Ferne, T. \& Rupp, A. A. (2007). A synthesis of 15 years of research on DIF in language testing: Methodological advances, challenges, and recommendations. Language Assessment Quarterly, 4(2), 113-148. https://doi.org/10.1080/15434300701375923

Flowerdew, J. \& Miller, L. (2005). Second Language Listening: Theory and Practice. Cambridge: Cambridge University Press.

Chung, Y-R. (2017). Validation of technology-assisted language tests. Teoksessa C. A. Chapelle \& S. Sauro (toim.), The Handbook of Technology and Second Language Teaching and Learning (s. 332-347). Wiley Blackwell. https://doi.org/10.1002/9781118914069.ch22

Hildén, R. \& Rautopuro, J. (2014a). Ruotsin kielen A-oppimäärän oppimistulokset perusopetuksen päättövaiheessa 2013. Kansallinen koulutuksen arviointikeskus \& Opetushallitus. Julkaisut 2014:1.

Hildén, R. \& Rautopuro, J. (2014b). Saksan kielen A-oppimäärän oppimistulokset perusopetuksen päättövaiheessa 2013. Kansallinen koulutuksen arviointikeskus \& Opetushallitus. Julkaisut 2014:4. 


\section{Ainedidaktiikka 5(1) (2021)}

Härmälä, M., Huhtanen, M. \& Puukko, M. (2014). Englannin kielen A-oppimäärän oppimistulokset perusopetuksen päättövaiheessa 2013. Kansallinen koulutuksen arviointikeskus \& Opetushallitus. Julkaisut 2014:2.

Kaftandjieva, F. \& Takala, S. (2002). Relating the Finnish Matriculation Examination English Test Results to the CEF Scales. Paper presented at the Seminar on linking Language Examinations to CEFR. Helsinki, June 30 - July 2, 2002.

Juurakko-Paavola, T. \& Takala, S. (2013). Ylioppilastutkinnon kielikokeiden tulosten sijoittaminen Lukion opetussuunnitelman perusteiden taitotasoille. Ylioppilastutkintolautakunta. Haettu 25.02.2021 osoitteesta https://www.ylioppilastutkinto.fi/images/sivuston_tiedostot/Raportit tutkimukset/FI_2013 kielikokeet taitotasot.pdf

Juurakko-Paavola, T. \& Takala, S. (2017). Kohti kriteeriperustaista arviointia ylioppilastutkinnon kielikokeissa. Teoksessa V. Britschgi \& J. Rautopuro (toim.), Kriteerit puntarissa. Kasvatusalan tutkimuksia 74 (s. 41-62). Jyväskylä: Suomen kasvatustieteellinen seura.

Juurakko-Paavola, T. (2016). Skillnader mellan könen i studentprovet i medellång svenska. Teoksessa J. Kolu, M. Kuronen \& A.. Palviainen (toim.), Svenskan $i$ Finland 16 (s. 42-57). University of Jyväskylä: Jyväskylä Studies in Humanities 298. http://urn.fi/URN:ISBN:978-951-39-6828-1

Juurakko-Paavola, T. (2019). Relating Finnish Matriculation Examination Grades to the CEFR. Teoksessa A. Huhta, G. Erickson \& N. Figueras (toim.), Developments in Language Education. A Memorial Volume in Honour of Sauli Takala (s. 147-151). EALTA - European Association for Language Testing and Assessment. University of Jyväskylä, Centre for Applied Language Studies.

Kane, M. (2006). Validation. Teoksessa R. Brennan (toim.), Educational measurement (s. 17-64). (4. painos). Westport, Ct.: Praeger Publishers.

Kansallinen koulutuksen arviointikeskus (2020). Koulutuksen arviointisuunnitelma 2020-2023. Helsinki: Kansallinen koulutuksen arviointikeskus.

Kunnan, A. J. (2018). Evaluating language assessments. New York: Routledge

Opetushallitus (2003). Lukion opetussuunnitelman perusteet. Helsinki: Opetushallitus.

Opetushallitus (2015). Lukion opetussuunnitelman perusteet. Helsinki: Opetushallitus.

Opetushallitus (2019). Lukion opetussuunnitelman perusteet. Helsinki: Opetushallitus.

Toulmin, S. (2003). The Uses of Argument. Cambridge: Cambridge University Press.

Wagner, E. \& Ockey, G. J. (2018). An overview of the use of audio-visual texts on L2 listening tests. Teoksessa G. J. Ockey \& E. Wagner (toim.), Assessing L2 listening: Moving towards authenticity (s. 129-144). Amsterdam: John Benjamins Publishing Company.

YTL (2011). Toisen kotimaisen kielen ja vieraiden kielten kokeiden määräykset. Ylioppilastutkintolautakunta. Haettu 6.7.2020 osoitteesta https://www.ylioppilastutkinto.fi/images/sivuston tiedostot/Ohjeet/Koekohtaiset/fi maaraykset kielikokeet.pdf

YTL (2020a). Toisen kotimaisen kielen ja vieraiden kielten kokeiden määräykset. Ylioppilastutkintolautakunta. Haettu 2.6.2020 osoitteesta https://www.ylioppilastutkinto.fi/images/sivuston tiedostot/Ohjeet/Koekohtaiset/kielikokeet maaraykset fi.pdf? $\mathrm{v}=040320$

YTL (2020b). Hyvän vastauksen piirteet. Ylioppilastutkintolautakunta. Haettu 7.8.2020 osoitteesta https://www.ylioppilastutkinto.fi/ylioppilastutkinto/hyvan-vastauksen-piirteet

YTL (2020c). Ylioppilastutkintolautakunnan verkkosivut. Ylioppilastutkintolautakunta. Haettu 25.6.2020 osoitteesta https://www.ylioppilastutkinto.fi/

von Zansen, A. (2019). Uudenlaista kuullun ymmärtämistä - Kuvan ja videon merkitys ylioppilastutkinnon kielikokeissa. (Väitöskirja). Jyväskylän yliopisto. http://urn.fi/URN:ISBN:978-951-39-7961-4 